I N T ER N ATIONAL MONETARY FUND

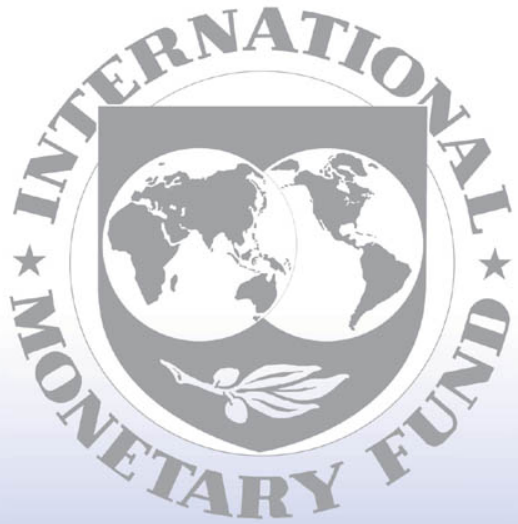

Staff

Country

Reports 


\title{
Algeria: 2002 Article IV Consultation-Staff Report; Staff Statement; and Public Information Notice on the Executive Board Discussion
}

Under Article IV of the IMF's Articles of Agreement, the IMF holds bilateral discussions with members, usually every year. In the context of the Article IV consultation with Country A, the following documents have been released and are included in this package:

- the staff report for the 2002 Article IV consultation, prepared by a staff team of the IMF, following discussions that ended on November 2, 2002, with the officials of Algeria on economic developments and policies. Based on information available at the time of these discussions, the staff report was completed on January 22, 2003. The views expressed in the staff report are those of the staff team and do not necessarily reflect the views of the Executive Board of the IMF.

- a staff statement of February 24, 2003 updating information on recent developments.

- a Public Information Notice (PIN) summarizing the views of the Executive Board as expressed during its February 24, 2003 discussion of the staff report that concluded the Article IV consultation.

The document(s) listed below have been or will be separately released.

\section{Selected Issues Paper and Statistical Appendix}

The policy of publication of staff reports and other documents allows for the deletion of market-sensitive information.

To assist the IMF in evaluating the publication policy, reader comments are invited and may be sent by e-mail to publicationpolicy@imf.org.

Copies of this report are available to the public from

International Monetary Fund - Publication Services

$70019^{\text {th }}$ Street, N.W. - Washington, D.C. 20431

Telephone: (202) 623-7430 - Telefax: (202) 623-7201

E-mail: publications@imf.org • Internet: http://www.imf org

Price: $\$ 15.00$ a copy

\author{
International Monetary Fund \\ Washington, D.C.
}


INTERNATIONAL MONETARY FUND

\section{ALGERIA}

\section{Staff Report for the 2002 Article IV Consultation}

Prepared by the Staff Representatives for the 2002 Consultation with Algeria

Approved by George T. Abed and Matthew Fisher

January 22,2003

- The discussions for the 2002 Article IV consultation were held in Algiers from October 19 to November 2, 2002. These discussions followed the Managing Director's visit to Algiers on October 16 and 17, 2002.

- The mission comprised Messrs. Lazare (head), Abdallah, Callier, Duran, and Ms. Koranchelian (all MED).

- The mission met with the governor and senior officials of the Bank of Algeria; the ministers of finance, trade, and participation and promotion of investment; the delegate minister for financial reform; the delegate to the Economic Recovery Plan; the delegate to economic planning; and their senior staff. The mission also met with officials of the National Statistics Office, a number of social security and other public agencies, and banking, corporate, and civil society representatives, including officials from the stateowned hydrocarbon company, Sonatrach.

- The authors of the report are Messrs. Lazare, Abdallah, Callier, Duran, and Ms. Koranchelian. 


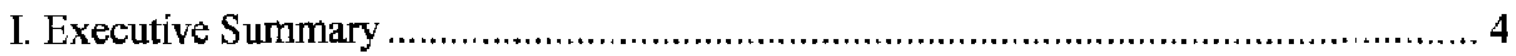

II. Introduction.

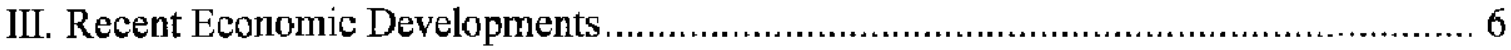

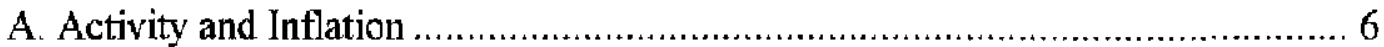

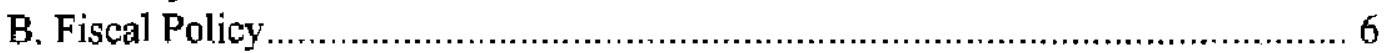

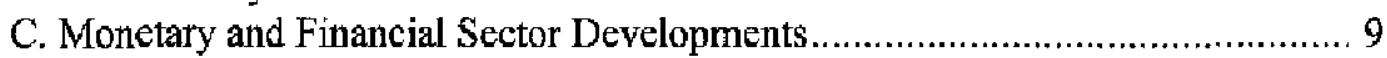

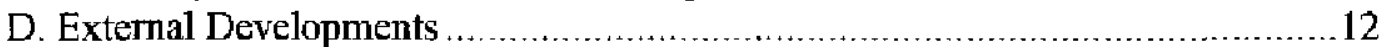

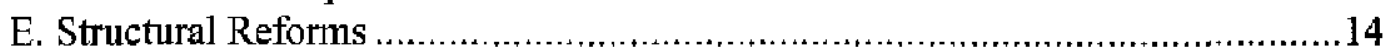

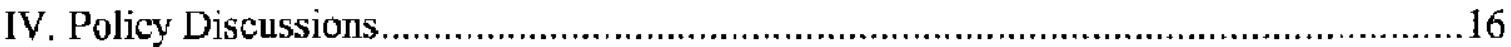

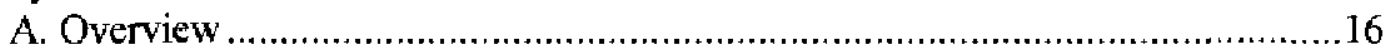

B. The Macroeconomic Framework for 2002-03 ….................................18

C. The Medium-Term Framework and Capacity to Repay the Fund ..................19

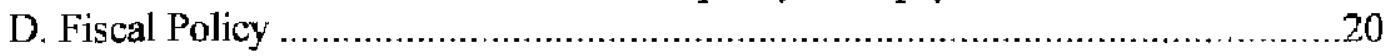

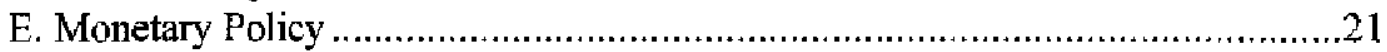

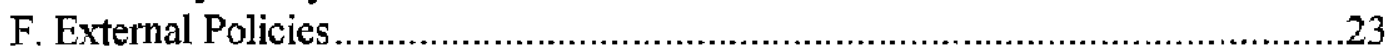

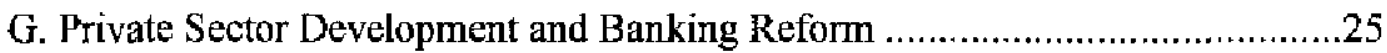

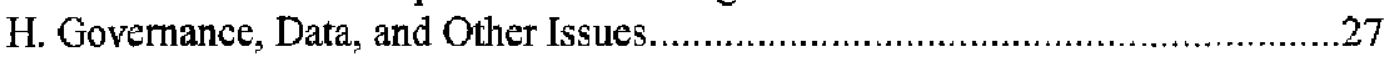

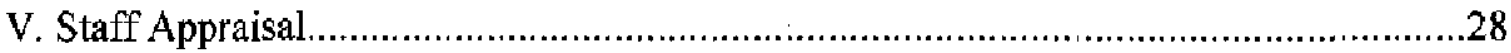

Tables

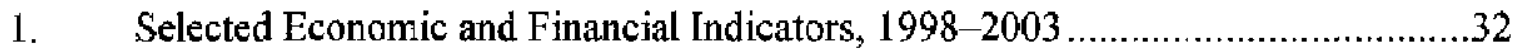

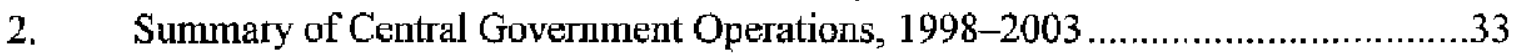

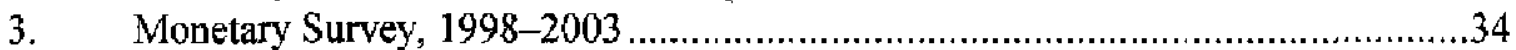

4. $\quad$ Balance of Payments, 1998-2003 …...................................................... 35

5. $\quad$ Illustrative Medium-Term Scenarios, 2001-07 ..............................................36

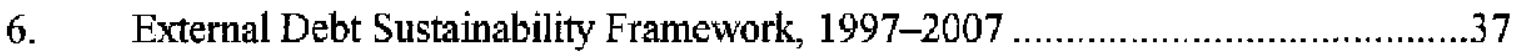

\section{Charts}

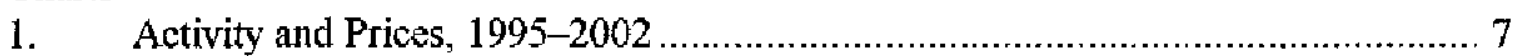

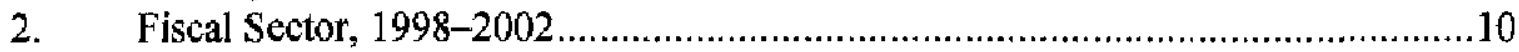

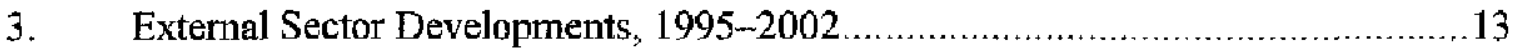

4. Amortization of External Debt, Outstanding as of December 31, 2001 ..............24

Boxes

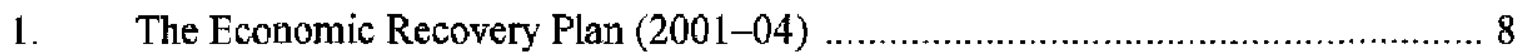

2. Monetary Policy Framework ....................................................................11

3. The 2001-02 Customs Tariff Reform .......................................................14

4. Structural Reforms-Past Achievements and Remaining Agenda .....................15 


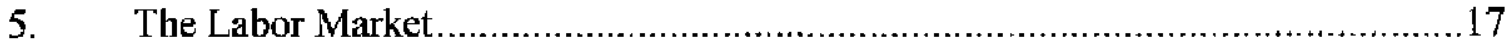

6. What are the Possible Sources of Sustained Growth in Algeria? .......................18

7. Would Inflation Pick Up in an Environment of High Money Growth? ................22

8. Private Sector Development ................................................................26

\section{Appendices}

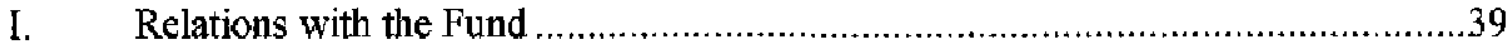

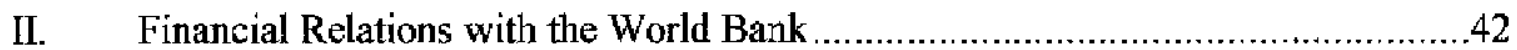

III. Statistical Issues.....................................................................................44

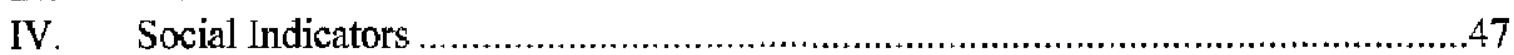

V. Draft Background Section of the Press Information Notice (PIN) …................48 


\section{EXECUTIVE SUMMaRY}

- Higher expenditures coupled with lower hydrocarbon output and prices resulted in a deterioration of the fiscal stance and a lower balance of payments surplus in the first half of 2002. Real nonhydrocarbon sector growth excluding agriculture has remained modest, with a slight improvement owing in part to the government's Economic Recovery Plan (ERP).

- Despite a tightening of the monetary stance, excess reserves of banks have increased considerably due to the reduction of sterilization of net foreign assets combined with sizable debt service payments by the treasury to banks following its assumption of banks' nonperforming loans. So far, however, this has not translated into higher inflation as the Consumer Price Index (CPI)-following a jump in 2001-fell in the first ten months of 2002 due to lower food prices.

- Structural reforms have largely stalted since the summer of 2001. In particular, no new privatization or restructuring of nonfinancial enterprises has occurred, and the government has not yet approved the draft law liberalizing the hydrocarbon sector nor has it transmitted to parliament the draft law establishing negotiable rights for use of state-owned agricultural land. Also, progress in banking reform was disappointing, aside from the completion of the financial restructuring of public banks.

- While acknowledging that the fiscal expansion initiated in 2001 is not a substitute for structural reforms and that the private sector should eventually take the lead in generating sustainable growth, the authorities are encouraged by the recent slight improvement in growth and employment and intend to push through their current expenditure program past the ERP's horizon of 2004. They are comforted by the high level of reserves accumulated so far, which would enable them to carry out their program for some time irrespective of oil market developments.

- The staff agrees that the looser fiscal stance does not endanger the balance of payments nor the treasury position as long as oil prices remain high; however, it notes that the beneficial effects of the stimulus will be temporary and limited in scope. Moreover, the increase in expenditures will inflate the weight of the public sector in the economy. The declining quality of public expenditure is also a concern. Furthermore, the staff stresses that the procyclical policy carries the risk of igniting inflation; it will also deplete the reserves accumulated in the oil stabilization fund during periods of high oil prices, thereby increasing adjustment costs in the event of an oil price downturn.

- The staff emphasizes that sustainable higher growth requires an acceleration of productivity-boosting structural reforms, including privatization, public sector restructuring, banking sector reform, and further trade liberalization. Meanwhile, the staff urges the authorities to adopt a more conservative fiscal stance as well as give higher priority to expenditures that support structural reforms. 


\section{INTRODUCTION}

1. On May 26, 1999, a year after the expiration of the Fund-supported Extended Arrangement, the Executive Board approved Algeria's request for SDR 223.5 million purchase under the Compensatory and Contingency Financing Facility (CCFF). Algeria's obligations to the Fund under the General Resources Account amounted to 78.5 percent of its quota at the end of November 2002 (Appendix 1). In September 1997, Algeria accepted the obligations under Article VIII, Sections 2, 3, and 4. Algeria maintains an exchange system free of restrictions on payments and transfers for current international transactions. Algeria is on the standard 12-month consultation cycle.

2. The 2001 Article IV consultation was concluded on August 29, 2001. Executive Directors commended the authorities' prudent macroeconomic management. Directors noted that higher economic growth was needed to reduce unemployment and improve living standards. In this context, they stressed that the fiscal stimulus introduced in 2001 would have to be complemented by an acceleration of structural reforms to strengthen growth on a sustainable basis. Directors emphasized the importance of privatization, restructuring of public enterprises, and comprehensive banking reform.

3. While security has tended to improve since the latter part of the 1990s, social and political tensions have grown starting in 2001 . The potitical and security improvements in 1999-2000 were primarily due to President Bouteflika's peace initiative (Civil Concord). However, incidents of violence have persisted in a few regions, including occasionally in Algiers, and-since the spring of 2001--political and cultural conflicts have erupted in the Berber-speaking region of Kabylia and sporadically in other parts of the country.

\section{Following the June 2002 parliamentary elections, Mr. Ali Benflis was} reappointed as prime minister. The program of the new government remains broadly similar to the previous government's program and confirms its intention to promote market-oriented reforms.

5. Algeria's relations with the World Bank currently focus on technical assistance and implementation of ongoing projects. The World Bank has approved only limited new lending to Algeria in 2001-02, and disbursement under the existing loan portfolio has been slow (Appendix II). The World Bank is preparing a Country Assistance Strategy to be completed by June 2003.

6. As noted by the recent statistical multitopic technical assistance mission, persistent data weaknesses exist in major areas, especially in government finance statistics and price indices. Such data weaknesses hamper the monitoring of economic conditions and the formulation of economic policies. 


\section{RECENT ECONOMIC DEVELOPMENTS}

\section{A. Activity and Inflation}

\section{Overall growth was sluggish in 2001 and the first part of 2002 , despite a better} performance in nonhydrocarbon sectors (Chart 1). In 2001, overall GDP growth of 2.1 percent was marginally lower than that in 2000 despite a sharp rebound in agriculture (Table 1). This slight decline reflected lower hydrocarbon output due to reduced OPEC oil quotas, while growth in the nonhydrocarbon sector rose to 4.5 percent (from 1.5 percent in 2000). Preliminary data for the first half of 2002, indicate divergent evolutions in different sectors, with a decline in agriculture due to adverse weather conditions and a pickup in construction and service activities due to the government's ERP initiated in 2001 (Box 1). As a result of the stronger growth of the nonhydrocarbon sector (agriculture), the unemployment rate decreased from 29.5 percent in 2000 to 27.3 percent in 2001 .

8. Inflation increased in 2001 but receded in 2002. Average inflation, as measured by the CPI, jumped from 0.3 percent in 2000 to 4.2 percent in 2001-due in part to the wage increases granted at the beginning of 2001 and to higher food prices-while core inflation increased by only 3.1 percent. ${ }^{1.2}$ In the first eleven months of 2002 , the CPI fell by 2.2 percent relative to December 2001 owing to a subsequent drop in food prices. ${ }^{3}$ The CPI, excluding food prices, increased by 1.9 percent.

\section{B. Fiscal Policy}

\section{The overall budget balance weakened in 2001 and the first half of 2002 (Table 2} and Chart 2). This deterioration mainly reflected higher spending and a decline in bydrocarbon revenues. The overall balance dropped from a surplus of 9.8 percent of GDP in 2000 to a surplus of 3.4 percent of GDP in 2001 and recorded a deficit of about 3 percent (annualized) of the $2001 \mathrm{GDP}$ in the first semester of 2002. The nonhydrocarbon primary deficit, which had been stable at 26.6 percent of the nonhydrocarbon GDP (NHGDP) in 2001, widened in the first half of 2002 .

\footnotetext{
${ }^{1}$ The 15 percent increase of wages in the civil service in January 2001 encouraged similar increases in public enterprises and other sectors. In addition, a one-third increase in the minimum wage was decreed.

${ }^{2}$ Core inflation is defined as the increase in the CPI basket excluding food.

${ }^{3}$ The drop in food prices can be explained by (a) the growth in agriculture excluding cereals, following changes in the agricultural policy including the removal of some regulatory constraints, and (b) the abolition of the minimum duty values and their replacement by a temporary additional duty (TAD) in mid-2001, followed by a reduction in this duty in January 2002.
} 
Chart 1. Algeria: Activity and Prices, 1995-2002

Despite a rebound in agricultural output, economic growth continued to be shggish in 2001 , because of a decline in oil GDP.

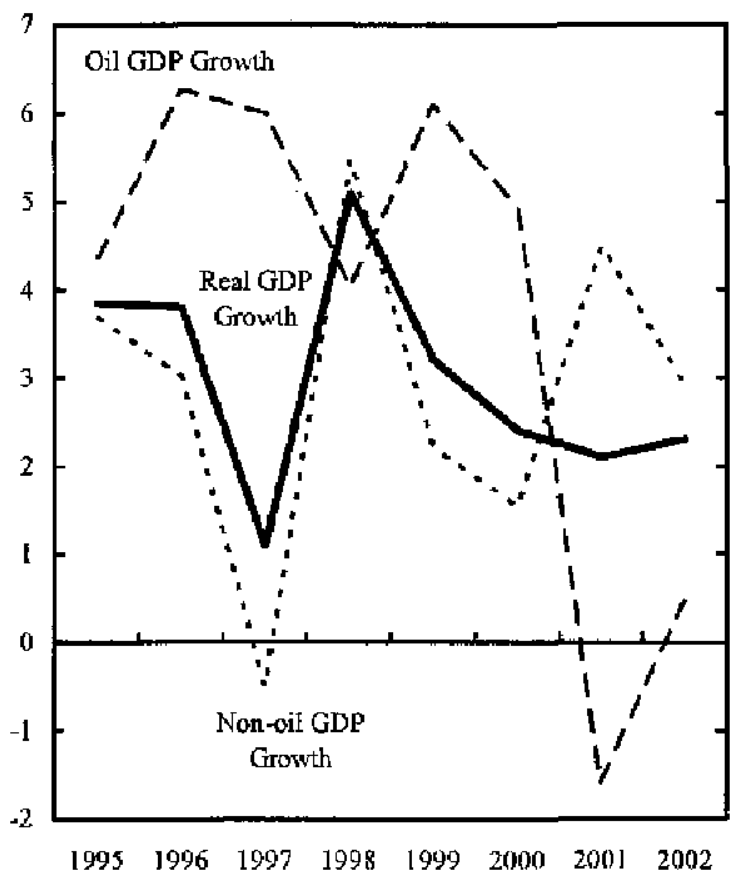

... and inflation picked up moderately in 2001 but receded in 2002 .
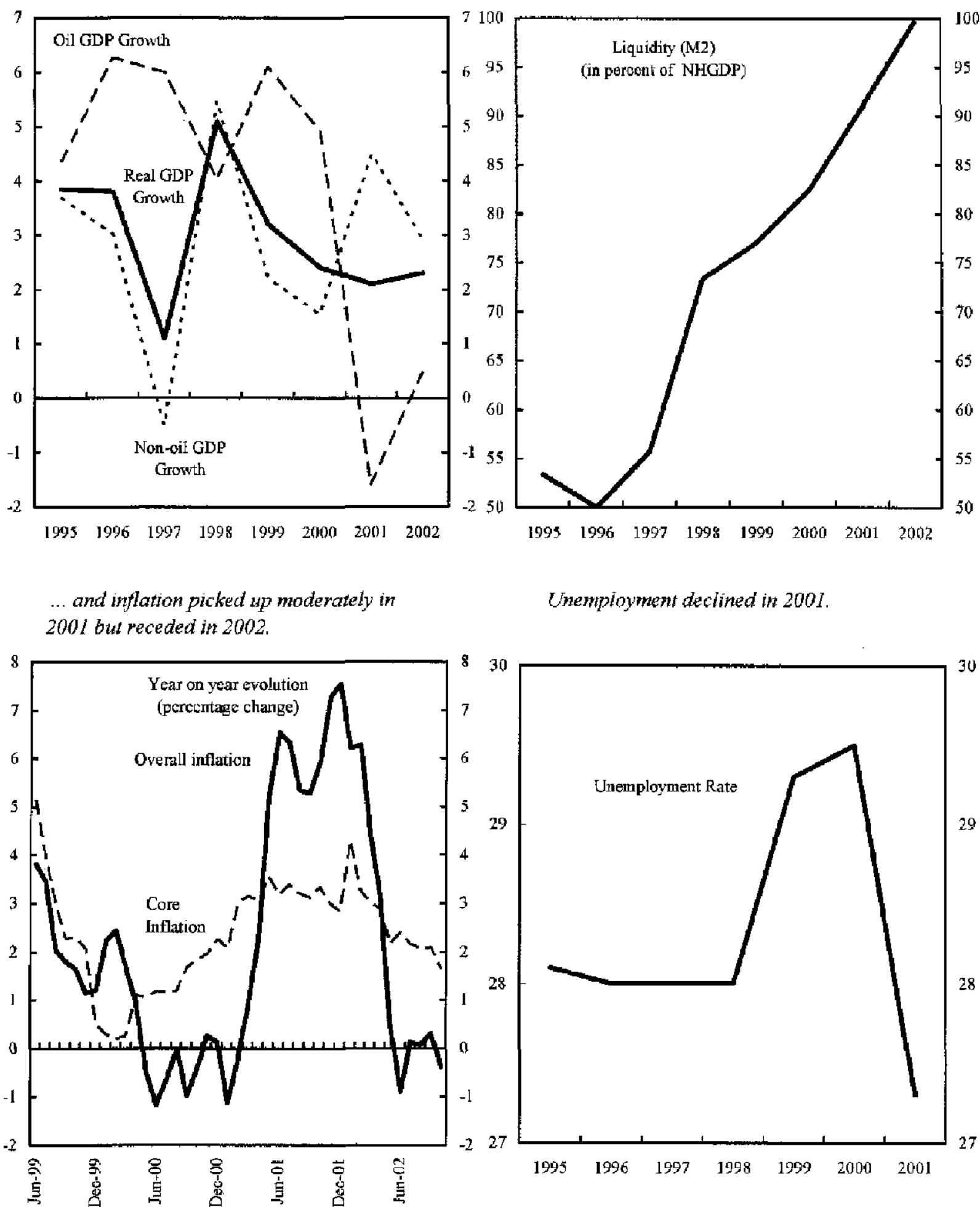

Unemployment declined in 2001.

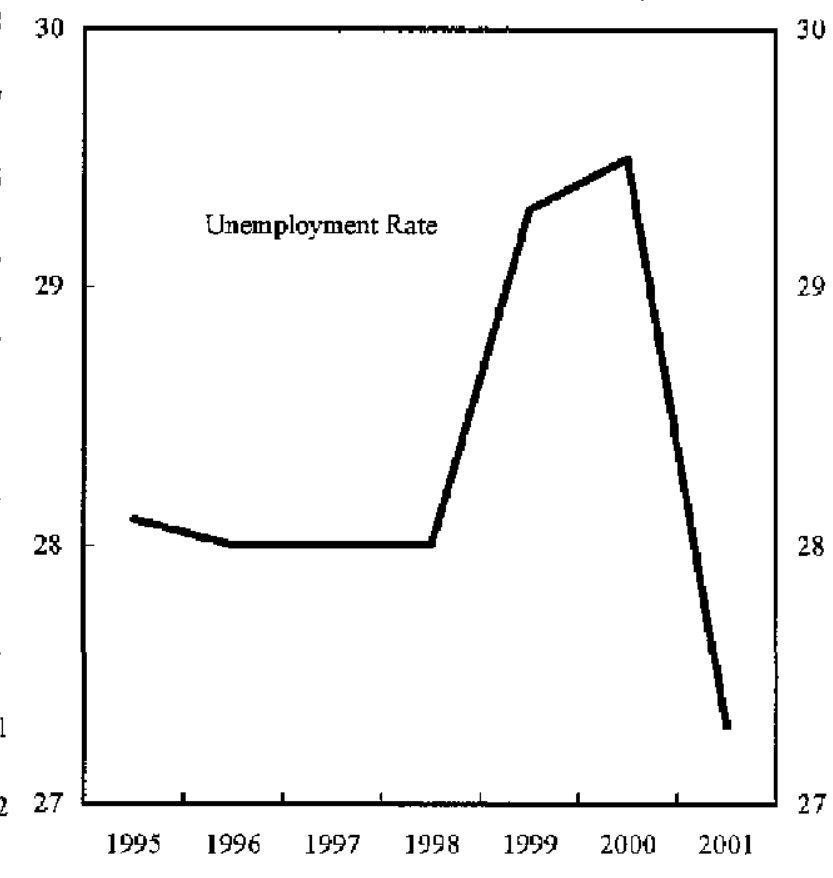

Sources: Algerian authorities and IMF staff estimates. 


\section{Box 1. The Economic Recovery Plan, 2001-04}

Faced with low growth, high unemployment, mounting social tensions, and increasingly outspoken criticisms over its perceived failure to use the large financial assets accumulated since end-1999 to relieve economic and social conditions, the government announced in April 2001 an Economic Recovery Plan (ERP). The ERP is a capital expenditure program which aims at disbursing a total of DA 525 billion (about 13 percent of the 2000 GDP) over 2001-04, in addition to regularly budgeted capital outlays.

The ERP's initially stated objectives were to (a) stimulare aggregate demand; (b) encourage labor-intensive activities, through increased support to agricultural production and to small- and medium-sized enterprises; (c) rehabilitate public infrastructure; and (d) develop humam resources. The ERP was introduced as a supplement, not a substitute, to structural reforms.

Following a slow initial implementation and supply bottlenecks in 2001, the government dropped its initial hopes that the ERP would stimulate growth to the 5-6 percent range in 2002-04. The authorities empliasized instead the beneficial impact of the plan on agriculture, local development, housing, and employnent as the main rationale for its adoption. Indeed, available information shows that project implementation in these areas has been brisk in the first half of 2002 .

The initial expected schedule for the related budget authorizations and their breakdown by main area is as follows:

Program Authorizations by Main Area (In billions of Algerian dinars)

\begin{tabular}{lrrrrr}
\hline & 2001 & 2002 & 2003 & 2004 & $2001-04$ \\
\hline $\begin{array}{l}\text { Direct support to agricultural } \\
\text { production and fishing }\end{array}$ & 10.6 & 20.3 & 22.5 & 12.0 & 65.4 \\
Local development & 32.4 & 42.9 & 35.7 & 3.0 & 114.0 \\
Public works & 93.0 & 77.9 & 37.6 & 2.0 & 210.5 \\
$\quad$ Of which: & & & & & \\
$\quad$ Water management & 5.4 & 15.8 & 10.1 & 0.0 & 31.3 \\
$\quad$ Railways & 9.7 & 28.9 & 16.0 & 0.0 & 54.6 \\
$\quad$ Roads & 24.5 & 5.8 & 0.6 & 0.0 & 30.9 \\
Human resources development & 39.4 & 29.9 & 17.4 & 3.5 & 90.2 \\
Other reforms & 30.0 & 15.0 & 0.0 & 0.0 & 45.0 \\
Total & 205.4 & 185.9 & 113.2 & 20.5 & 525.0 \\
$\quad$ As a percent of projected GDP & 4.7 & 4.0 & 2.2 & 0.4 & $\ldots$ \\
& & & & & \\
\hline
\end{tabular}

Source: Algerian authorities.

The initial plan was front-loaded, with about 75 percent of the budget authorizations in $2001-02$. However, implementation was slower, particularly for large infrastructure projects like railways and highways. The 2003 Budget Law anticipates that only 53 percent of the total DA 525 billion will be disbursed by end-2003. It projects overall capital expenditures of DA 614 billion in 2003, an increase of 12 percent over the allocations of the 2002 Supplementary Budget Law. Credit allocations for the ERP, at DA 118 billion in 2003, represent around one-fifth of that total. 
10. Overall, budget revenues to GDP continue to weaken. Intensified collection and enforcement efforts for the VAT in the first half of 2002, together with a widening of the base of customs duties, helped raise the tax revenue. However, the increase fell short of compensating for the decline in hydrocarbon revenues due to lower hydrocarbon prices and volumes. Hydrocarbon receipts dropped from 29.7 percent of GDP in 2000 to 24.1 percent of GDP in 2001, and fell by 19 percent (annualized) of 2001 GDP in the first half of 2002 .

\section{Expenditures continued to increase in 2001, fueled by increases in wages and} transfers, and surged in the first half of $\mathbf{2 0 0 2}$ compared to the corresponding period of 2001. The 2002 increase was driven mainly by a 63 percent increase in capital outlays due to markedly higher budget appropriations in the 2002 Budget Law and a higher execution rate due to efforts to accelerate the implementation of the ERP and other capital expenditures.

12. Expenditures are set to rise in 2003. The 2003 Budget Law (BL 2003) authorizes in particular a further 12 percent increase in capital expenditures, which includes the financing of the third tranche of the ERP; it also comprises measures aimed at updating and simplifying the tax system and reorganizing the tax and customs administrations, notably through the establishment of a large taxpayers unit (Direction des Grandes Entreprises, DGE) and a pilot centralized tax unit (Centre des Impots, CDI). These measures are expected to improve revenue over time, while others - such as the further lowering of the wage-based versement forfaitaire from 4 percent to 3 percent-may result in revenue losses in the short run, until employment responds to the reduced tax burden.

\section{Monetary and Financial Sector Developments}

\section{Money (M2) growth accelerated significantly in 2001 and the first half of 2002} fueled by a continuous increase in net foreign assets (Table 3). In 2001, the contribution of net foreign assets to monetary growth was partly offset by a small decline in domestic credit. However, in the first half of 2002 , the contribution of domestic credit to money growth turned positive.

\section{Since $\mathbf{2 0 0 1}$, excess reserves of banks have increased considerably despite a} tightening of monetary policy. Following the signature of conventions formalizing the assumption by the treasury of banks' nonperforming loans (in an amount of DA 528 billion or 12.5 percent of the 2001 GDP), the treasury made sizable debt servicing payments to the public banks in late 2001 and early 2002 . While the liquidity position of banks had already improved considerably since 2000 due to higher deposits by the oil sector, these treasury payments resulted in the emergence of excess liquidity in the banking system. Furthermore, during the first semester of 2002 , the liquidity impact of the increase in net foreign assets of the central bank was reinforced by a monetary financing of government expenditures. 
Chart 2. Algeria: Fiscal Sector, 1995-2002

The overall fiscal balance weakened in 2001 and $2002 \ldots$ ...reflecting lower hydrocarbon revenues...

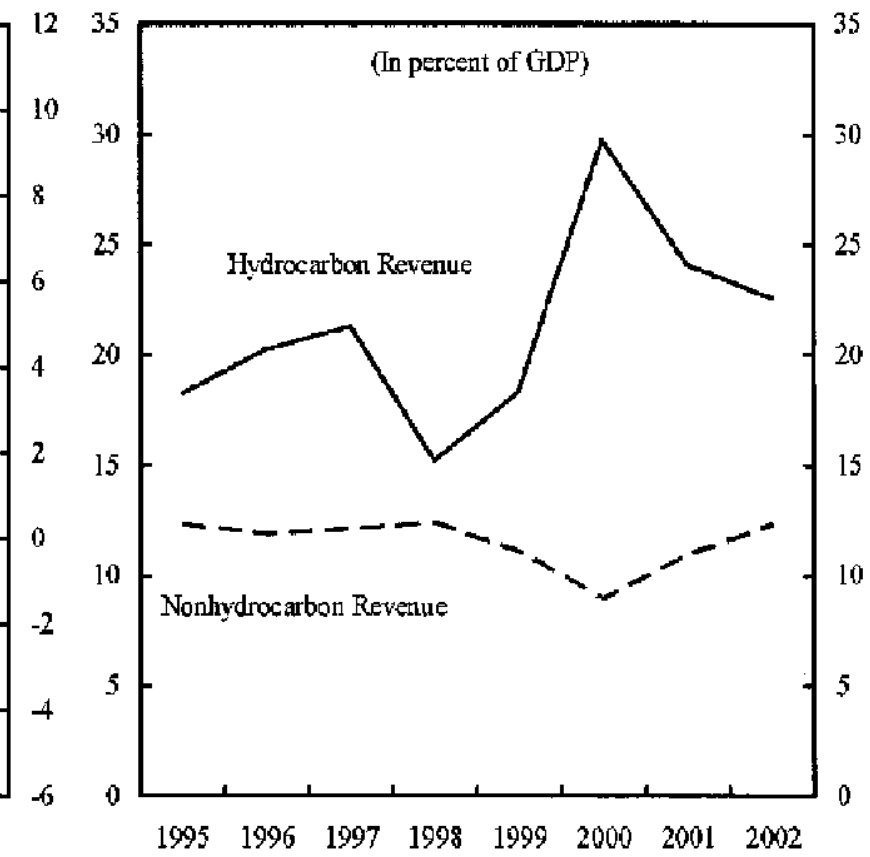

As a result, the fiscal impulse increased. ...and higher expenditure, in particulor capital expenditure.

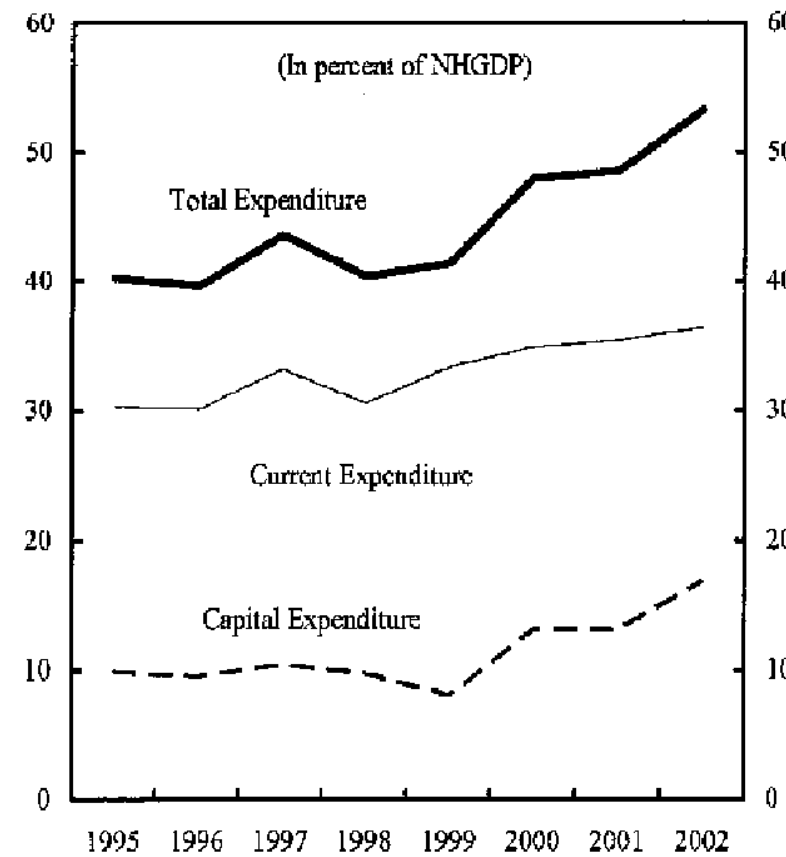

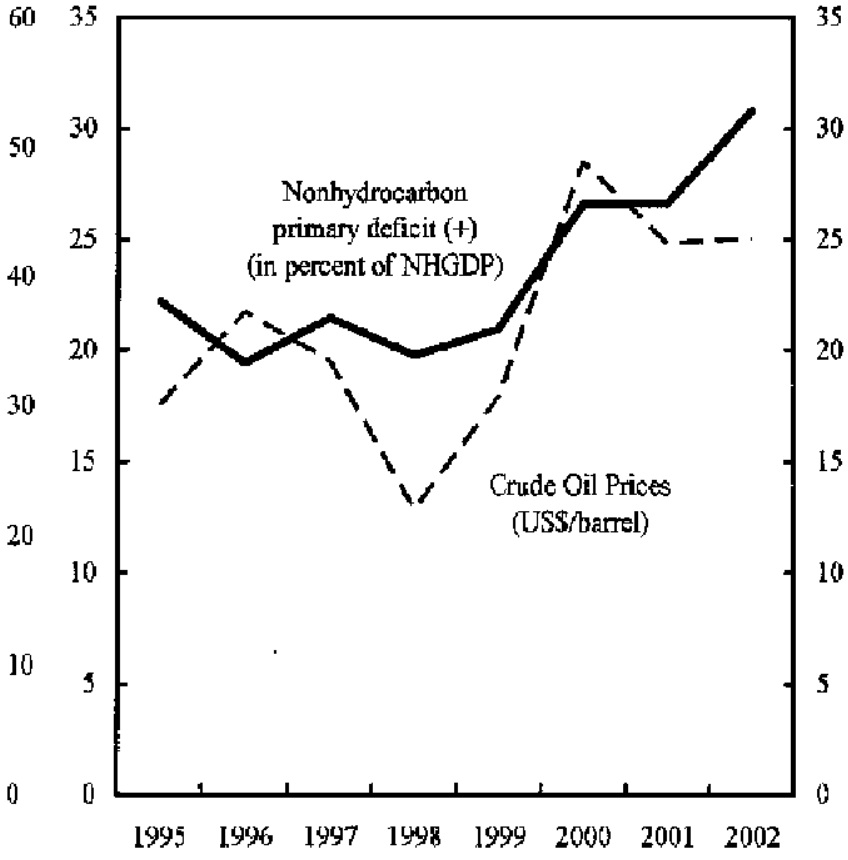

Sources: Algerian authorities and IMF staff estimates. 
Despite a tightening of the monetary stance in late 2001 through an increase in reserve requirements (from 3 percent to 4.25 percent), and the introduction in April 2002 of a new facility (negative liquidity auctions) to absorb bank liquidity, excess liquidity has remained sizable, leading to a drop in the interbank rate (Box 2$){ }^{4}$

\section{Box 2. Monetary Policy Framework}

Monetary policy aims at stabilizing prices in the economy. As defined by the 1990 law on Money and Credit, the policy objective is relatively broad. ${ }^{1}$ In practice, the Bank of Algeria gives much weight to price stability in its policy making.

The choice of the intermediate target in Algeria has evolved. During 1994-1998, the intermediate monetary policy objective was the net domestic assets of the Bank of Algeria. Since then, growth of base money has been carefully monitored. In practice, the M2 aggregate also receives particular attention.

Since the early 1990 s, monetary policy has increasingly been conducted through indirect monetary instruments: reserve requirements; instruments to inject or withdraw liquidity (e.g., credit anctions), permanent refinancing facilities available to banks for use at their initiative (e.g., rediscount facility, overdraft facility); and interventions on the foreign exchange market. Open market operations were introduced in 1996 but are rarely used.

The negative liquidity auction introduced in April 2002 to mop up excess liquidity from the banks is currently the main instrument used by the Bank of Algeria.

Monetary management is hampered by several factors: (a) the strong dependence of the Algerian economy on hydrocarbon export revenues, and the resulting swings in bank liquidity; (b) the weak development of the market in treasury securities and the financial market in general; (c) the lack of marketable government securities in the Bank of Algeria's portfolio; (d) the lack of interest rate competition between state-owned banks; (e) the lack of sensitivity of nonfinancial public enterprises to interest rate variations; (f) the absence of formal liquidity forecasts for the fiscal sector; and (g) weaknesses of the statistics and payments systems.

'The monetary policy objective is defined by Article 55 of the Law on Money and Credit. It states that the central bank's mission is "to create and maintain, in the areas of money, credit, and foreign exchange, the necessary conditions for the orderly development of the national economy, by promoting the use of all of the productive resources of the country while safeguarding the internal and external stability of the currency."

\footnotetext{
${ }^{4}$ To absorb liquidity, the Bank of Algeria issues a call for deposits, remunerated at a preanounced interest rate (currently 2.75 percent) and maturity. These modalities arose from the absence of marketable securities in the Bank of Algeria's portfolio. In the initial transactions under this new facility, the Bank of Algeria has accepted only part of the liquidity offered by commercial banks.
} 
15. The functioning of the interbank market has improved. In 2002, the Bank of Algeria started to extend negative liquidity auctions to all local banks and introduced a Reuters screen for trading operations. Nevertheless, some banks are undertaking operations outside the interbank market, possibly to avoid relying on the Bank of Algeria as a broker.

16. In the area of banking reform, the treasury assumed the remaining identified nomperforming loans and recapitalized three public banks. This recapitalization (through infusion of cash and issuance of treasury securities) resulted in the official licensing of these banks. Banking supervision continued to be strengthened with the support of Fund technical assistance, and the modernization of the payments system was initiated with the World Bank assistance.

\section{External Developments}

17. The balance of payments remained in surplus in $\mathbf{2 0 0 1}$ and during the first half of 2002 (Chart 3 and Table 4), despite a drop of 4 percent of GDP in the current account in 2001 due to lower hydrocarbon revenues. In the first half of 2002, the current account surplus eroded further as hydrocarbon exports continued to decline and imports to increase, The capital account deficit narrowed to under $\$ 1$ billion in 2001, mainly as a result of higher net direct investments, which were boosted in part by the sale of a second cellular telephone license. The capital account continued to improve in the first half of 2002 due to a combination of higher drawings and lower amortization. Gross official reserves surged, from $\$ 11.9$ billion ( 12 months of imports) at end-2000 to $\$ 21.1$ billion at end-June 2002 . Following a trend that began in 1996 , gross external debt continued to decrease, to $\$ 22.6$ billion at end 2001 (from $\$ 25.3$ billion at year-end 2000 ). However, the debt service ratio increased to 22.8 percent of exports in 2001 (from 20.3 percent in 2000) mainly on account of lower exports.

18. Over the last two years, the average real effective exchange rate (REER) has remained broadly stable. In 2001 , it appreciated by 2.8 percent over its 2000 level, following two years of depreciation. However, in the first 10 months of 2002, it depreciated by 3.7 percent on a 12-month moving average basis. The spread between the exchange rate on the interbank market and the parallel market appears to have widened to about 20 percent, reflecting in part the increase in the economy's liquidity, and in part a larger demand for payments of underinvoiced imports following the elimination of the minimum duty values in the context of tariff reform (below). ${ }^{5}$

\footnotetext{
${ }^{5}$ With the advent of the external convertibility of the dinar for current account transactions following the 1994 reforms, the parallel market has reportedly considerably shrunk and its daily tunover volume is now relatively small compared to the official market. It covers mostly capital flight and other illegal transactions, tax and customs duties evasion on imports, remittances of Algerian workers abroad, and possibly some nontraditional exports. Small payments of services, such as travel abroad, are sometimes also conducted through this market owing to the commercial banks' failure to adequately and speedily implement the existing foreign exchange rules.
} 
Chart 3. Algeria; External Sector Developments, 1995-2002

Balance of payments surplus fell in $200 \mathrm{I}$

and 2002, mainly due to lower

hydrocarbon exports.
Meanwhile, the capital account improved.

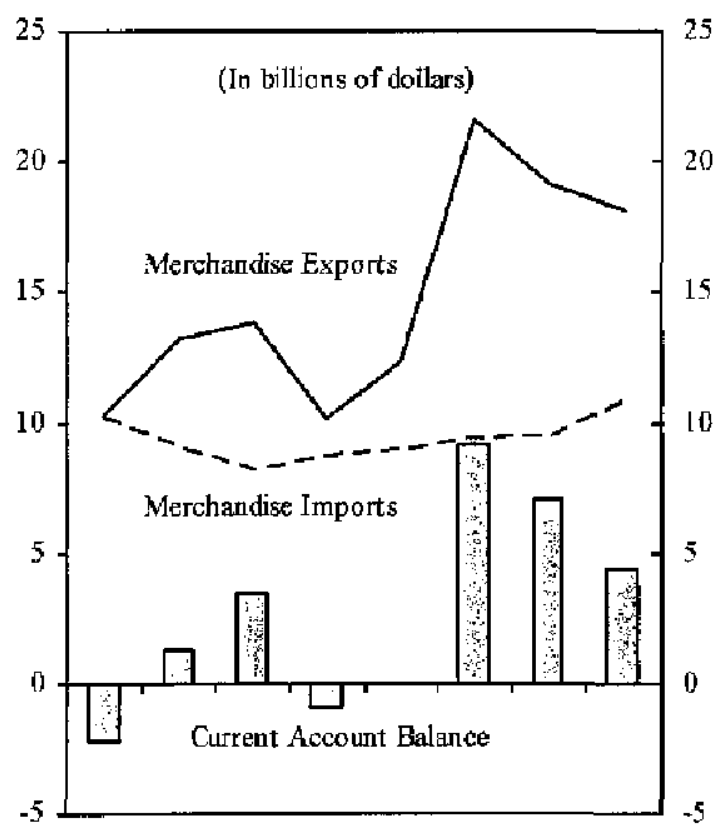

19951996199719981999200020012002

Official reserves increased, and external debt decreased.

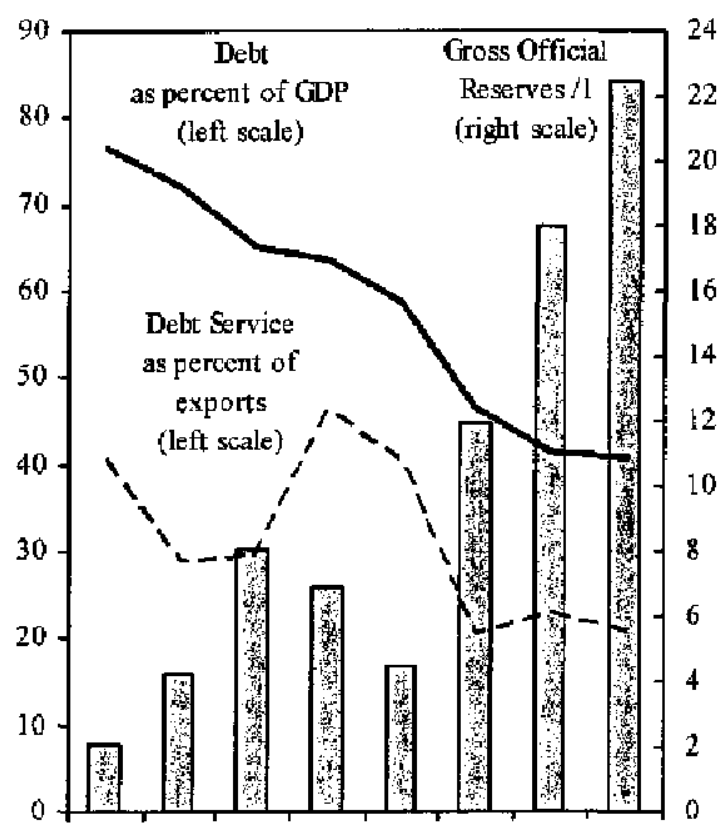

19951996199719981999200020012002

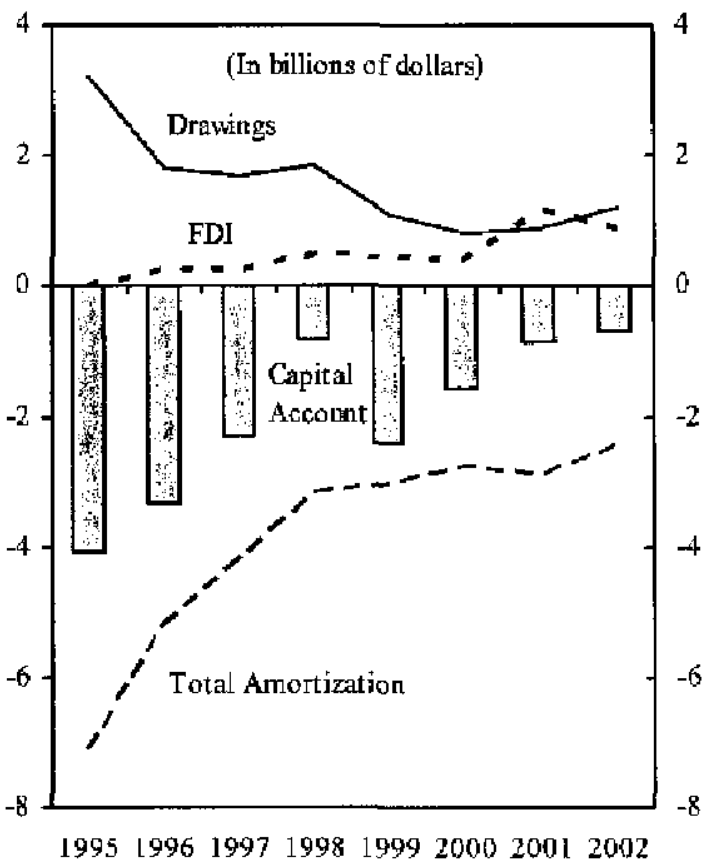

However, there is no sustained tendency towards an appreciation of the real affective axchange rate.

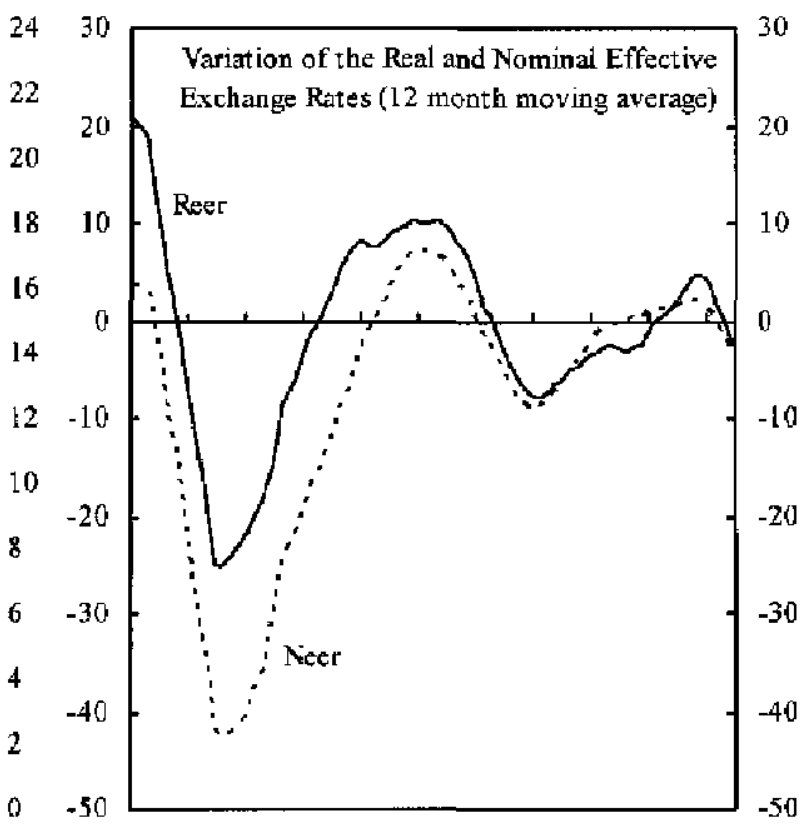

1994Ml 1995M9 1997M5 1999M1 2000M9 2002M5

Sources: Algenian authorities and IMF staff estinates.

1/ In billions of dollars 


\section{E. Structural Reforms}

\section{Structural reform efforts have largely stalled since the summer of $\mathbf{2 0 0 1}$. However,} some progress has been achieved in two areas:

- Economic liberalization. A comprehensive tariff reform was implemented in two stages from August 2001 (Box 3). In early 2002, the parliament approved a law liberalizing the electricity and gas sectors. Algeria signed, on April 22, 2002, an Association Agreement with the European Union (AAEU). In summer 2001, the ordinance reforming the tax code was signed. Negotiations toward accession to the World Trade Organization (WTO) are ongoing.

\section{Box 3. The 2001-02 Customs Tariff Reform}

The 2001-02 tariff reform intended to streamline the tariff and reduce the dispersion of the rates of the finalization of the Association Agreement with the European Union (AAEU) in 2002 and Algeria's accession to the World Trade Organization. ${ }^{1}$

First, in August 2001 the maximum rate was reduced from 45 percent to 40 percent and the minimum duty values were abolished. In order to continue protecting local enterprises in the transition period, a temporary additional duty (TAD) was introduced. ${ }^{2}$ Second, a new tariff with only three rates, in addition to the zero rate, became effective on January 1,2002 . The existing customs service fees, of 2 percent and 0.4 percent, were not affected by the reform nor were the exemptions and special regimes (such as the regime applicable to the hydrocarbon sector or the "promotion of investment").

The new tiriff can be summarized as follows: Raw materials and equipment goods Intermediate products

$5 \begin{array}{r}\text { Percent } \\ 15 \\ 30\end{array}$

Final products

The TAD will be progressively reduced and eventually eliminated in accordance with the following schedule: Percent

Introduction in July 2001

January 1, 2002

Jamuary 1, 2003

January 1, 2004

January 1, 2005

Jamuary 1, 2006

60
48
36
24
12
0

The AAEU will come into effect only after ratification of the agreement by Algeria and each of the members of the European Union (EU). It implies free trade in industrial products between Algeria and the countries of the EU 12 years after the implementation date. Free trade in equipment goods will come into force immediately upon effectiveness of the AAEU. Rates will be reduced progressively over 7 years for intermediate products and over 12 years for final products. The potential development of Algeria's agricultural exports is constrained by non tariff barriers in several major industrial countries, including nembers of the EU.

${ }^{2}$ In its discussion with the government, the staff noted that the list of tariff positions subject to the TAD, which was enlarged in February 2002 , includes a large number of goods that do not require this temporary protection. 
- Privatization and public sector restructuring. Two major transactions were completed in mid-2001: the assets of the public sector steel-making complex, SIDER, were transferred to a majority foreign-owned company; and a new cellular telephone license was sold to a private investor (for $\$ 737$ million). Joint ventures with foreign investors were also concluded in a limited number of cases. In addition, the institutional framework for the management of public sector enterprises was revised with a view to providing the government with more flexibility.

20. Further reforms are being prepared by the government (Box 4). Recently, the Council of State participation (CPE) approved, in principle, the opening of the capital of one of the six public banks through an international bidding process, as well as the privatization of other smaller nonfinancial enterprises, with a particular emphasis on entities facing financial or economic difficulties. However, the government has not yet approved the draft law liberalizing the hydrocarbon sector nor has it transmitted to parliament the draft law aimed at establishing land concession rights for the part of agriculture land, which is still state-owned.

\section{Box 4. Structural Reforms-Past Achievements and Remaining Agenda}

- Following a first wave of reforms introduced between 1987 and 1991 , the authorities formulated in 1994 a comprehensive three-year adjustment program supported by the Fund. ' ${ }^{\prime}$ Structural reforms under the program included: (a) an exchange system reform (leading to cursent account convertibility in 1997); (b) price, trade, and payments liberalization; (c) public enterprise reform (including the liquidation of numerous local public enterprises); (d) modernization of monetary policy instruments; (e) establishment of the institutional foundation for the development of the financial sector; (f) strengthening of the safety net (including the creation of an unemployment insurance mechanism).

- Following the completion of Fund-supported programs in 1998, reforms continued in a number of areas, but the pace of reforms slowed down considerably, particularly since summer 2001. Areas where reforms were introduced included: trade liberalization; tax administration reform; banking supervision; and the modernization of the institutional framework in mining, electricity, and telecommunications to open these sectors to private sector participation. One major privatization took place and a cellular telephone license was sold to a private operator.

- The government has announced its intention ta implement further reforms, including: (a) privatization of the nonfinancial public enterprises (with the emphasis on smaller enterprises facing financial and economic difficulties); (b) opening of the capital of one state-owned bank to private participation, and creation of partnership with private banks in the management of other state-owned banks; (c) establishment of a legal mechanism to allow the transfer of rights on agricultural land; and (d) accession to the World Trade Organization (WTO).

- In addition, the staff recommend that priority reforms also include: (a) replacement of bank credit to lossmaking public enterprises with temporary budget subsidies in the context of a restructuring program; (b) privatization of state-owned banks and all viable nonfinancial enterprises (with the exception of the oil company, Sonatrach); (c) further liberalization of the foreign exchange regulations; (d) further trade liberalization, to accompany the implementation of the association agreement with the European Union; (e) assignment of property rights on industrial, residential, and agricultural land together with the establishment of an efficient cadastre; (f) strengthening of the judiciary as a service supporting the development of the private sector; and ( $\mathrm{g}$ ) reduction of disincentives to employment in the formal sector.

For a comprehensive description, see Nashashibi and others, Algeria: Stabilization and Transition to the Market, Occasional Paper 165, RMF, 1998. 


\section{Policy Discussions}

\section{A. Overview}

\section{Over the last few years, Fund surveillance has focused on growth and oil revenate} management issues. Algeria established a strong record of policy implementation and broadly achieved its stabilization objectives under the four years of Stand-By and Extended Arrangements completed in 1998. However, its economy still suffers from growth well-below potential and high unemployment (Box 5). Against this background, since 1998, the staff has highlighted an acceleration of productivity boosting reforms in the context of a stable macroeconomic environment, as well as a sound use of oil revenues, as key policy challenges to achieve sustainable higher growth. The authorities welcomed the Fund's advice and considered surveillance and technical assistance recommendations particularly valuable inputs in the design and implementation of their policies. On balance, however, while the staff has continuously emphasized the urgency of structural and institutional reforms to establish the foundations of private sector-led growth and the need for caution in the use of volatile hydrocarbon revenue, the pace of reform has been markedly slow; the authorities have stressed since 2001 that existence of large budgetary and international reserves has allowed for a more expansionary stance to stimulate growth in the short term.

\section{Increased political and social tensions in a context of high oil revenues led the} authorities to introduce the ERP in the spring of 2001, in order to create jobs and improve the living conditions of the population, particularly in areas where public infrastructure had been damaged in the mid-to-late 1990 s by terrorist attacks. In their discussions with the staff, the authorities expressed confidence in the success of their policies, noting the improvement in the living standards of the population generated by these expenditures. They stressed their intention to maintain over time the current relaxed fiscal stance, which--in their viewprovides a temporary boost to the economy. They also underlined that this policy does not threaten macroeconomic stability as shown by the very low inflation outcome in 2002 , and it remains financeable for the next two years or so even in the event of a pronounced downturn in oil prices, thereby providing time to adjust expenditure if the shock is sustained. However, the authorities acknowledged that the higher growth needed to reduce unemployment and durably improve standards of living would have to be generated by private sector development. The government confirmed its intention to accelerate the pace of structural reforms, including privatization.

23. The staff stressed the risks carried by the government's current policies, especially in the fiseal and monetary areas. The staff indicated that the surge in fiscal expenditure would have only a limited and temporary impact on growth, while increasing the weight of the public sector in the economy and reducing the quality of expenditure. In addition, the increase in liquidity generated by the lack of sterilization of the inflows of foreign assets carries over time a significant inflationary risk. 


\section{Box 5. The Labor Market}

Labor supply is growing fast. Population growth in Algeria has been historically among the highest in the world. It still averaged 3.1 percent during $1977-98$ and about 1.5 percent in the recent years. This fast growth has translated into rates of growth of the young adult population (ages 15-34) in excess of 3.8 percent per year in the 1980s. The working age population is expected to continue growing at high rates for the next twenty years. As a result of the above, and of increasing participation rates, labor force growth averaged 3.4 percent during the 1990 s and resulted in an estimated annual average of 250,000 new entrants in the job market.

The fall in growth performance since the mid-1980s resulted in soaring unemployment rates. From independence to the early 1980 s, strong economic growth averaging over 6 percent annually ailowed Algeria to absorb new job entrants faster than labor force growth to support the rapid expansion of public services in education and bealth. However, with the advent of the 1986 oil shock, Algeria embarked on a prolonged economic crisis that slashed average growth down to 1.5 percent annually, and saw unemployment soaring from 19.8 percent in 1990 to 29.5 percent in 2000 despite attempts to mitigate ts effects through further civil service growth. With productivity in the public sector already lagging behind the private sector, the higher share of public employment resulted in negative productivity growth rates and corresponding fall in real wages. Unemployment mainly affected the young ( 80 percent of the unemployed are under 30 ), first time job seekers ( 76 percent of total), the less educated, urban dwellers, and females. However, official data may significantly overestimate the magnitude of unemployment as the informal sector is thought to have expanded in the $1990 \mathrm{~s}$

In response to high unemployment, the government actively promoted in the $1990 \mathrm{~s}$ an array of employment programs, including wage subsidies, micro-credit, public works, employment services and in-house training. A number of these programs have targeted the young unemployed. The two most important are:

- the Emplois Salariés d'Initiative Locale (ESLLs), which aim at providing low-skilled youth with maximum qualification and experience to enhance their employability. There were about 150,000 beneficiaries in 1998 (about 72,000 in full time equivalent); and

- the Indemnités d'Activités d'Intérêt Général (IAIG), which provide compensation for community based activities to the poor who are able to work.

- however, the above schemes, with few exceptions, have been inefficient, and their overall impact and coverage have been low. Over time, there has been a tendency to use the programs unsuccessfully as a mechanism to solve large-scale unemployment issues.

A more fruitful approach was the initiation in 1990 of reforms of the institutional and legislative framework to improve labor market flexibility and reduce taxes on labor. Law 90.1 1 allows employers greater flexibility in hiring and firing decisions and the use of short-term contracts. Other reforms allow free negotiations over salaries and working conditions, and introduce part-time and home work legislation. Since 2001, wage-based contributions (e.g., the versement forfailaire) have been reduced to foster employment opportunities, in the formal sector.

\section{Against this background, the staff recommended a more conservative fiscal} policy combined with an acceleration of structural reforms. It indicated that the following priorities should be established: (a) the privatization/restructuring of nonfinancial public sector enterprises; (b) banking reform and financial market development; (c) strengthening of economic institutions, such as the judiciary and statistical systems (Box 6). 


\section{Box 6. What are the Possible Sources of Sustained Growth in Algeria? ${ }^{1}$}

Despite very high investment rates and a rapid increase in the size and level of education of the labor force, growth in Algeria has been slow over the past two decades (2.3 percent for the period 1981-2001). Productivity growth has, therefore, been negative during most of the last three decades.

Sound economic policies and strong institutions have a mutually reinforcing impact on productivity and growth. Therefore, reinvigorating growth would require implementing economic and institutional reforms that should focus on three complementary building blocks: ensuring a sustained macroeconomic stability, accelerating structural reforms, and strengthening institutions.

On macroeconomic stability, there is a need to focus on safeguarding the sustainability of fiscal policy, as the fiscal stimulus is not a long-lasting solution for growth. In addition, it is important to consider the nonhydrocarbon balance in assessing the fiscal stance and avoid procycylical fiscal policies.

Accelerated structural reforms would fall into two challenges:

- developing a sound market-based financial system to increase the efficiency of resources allocation, including by privatizing public banks and strengthening prudential regulation $\mathrm{s}$ and supervision; and

- enabling private sector-led growth by privatizing/restructuring nonfinancial public sector enterprises, removing bottlenecks that are hampering the fonmal sector development, eliminating red tape, and ensuring competitive access to infrastructure, in particular to land.

Underpinning the above reforms is the need for institutional reform. Priorities would be the establishment of the basic legal framework of a market economy, including well-defined property rights (in particular for land ownership), enforceable contracts, and the security of an efficient, honest, and effective judiciary.

${ }^{1}$ See paper on "Sources and Institutional Underpinnings of Sustained Growth in Algeria" (forthcoming).

\section{B. The Macroeconomic Framework and Policies for 2002-03}

25. Despite an acceleration of growth in the construction sector, supported by the expansionary fiscal stance, GDP growth is expected to have remained sluggish in 2002 and modestly increase in $\mathbf{2 0 0 3}$. The disappointing performance in 2002 was partly due to adverse weather conditions and the scheduled maintenance of facilities in the hydrocarbon sector, which reduced the commercialization of natural gas. The projected higher growth rate in 2003 is based, in particular, on the assumption of more favorable weather conditions and a continued positive impact of the fiscal stimulus. In 2002, the drop in food prices will result in an average inflation rate of less than 2 percent, while inflation is projected to remain moderate in 2003.

26. Fiscal policy will continue to be expansionary in 2003. The strong increase in expenditures, coupled with a reduction in hydrocarbon revenues in 2002 , is expected to result in small budget deficits in 2002 and 2003. 
27. On the basis of average oil prices of US\$25 per barrel, the country's strong external position would improve further in 2003. The current account surplus is expected to hover around 8 percent of GDP in both 2002 and 2003, while the capital account deficit would be eliminated in 2003 as a result of a further increase in foreign investment, which would include the second payment of the second celtular telephone license sale. Gross external reserves would, therefore, increase further to above $\$ 22$ billion (about 20 months of imports) at end-2002 and $\$ 27$ billion (22 months of imports) at end-2003, thus exceeding from end2002 onwards the projected level of Algeria's external debt.

\section{Medium-Term Macroeconomic Framework and Capacity to Repay the Fund}

28. The stafrs baseline scenario projects low growth and a small budget deficit, but a strong external position (Table 5). Based on the World Economic Outlook (WEO) oil price projections - and in line with the ERP - it assumes a deceleration in public investment growth to a more sustainable pace from 2004 onwards, a continuation of the slow pace of structural reform, and stability of the real effective exchange rate. This results in a budget deficit of about 1 percent of GDP, continued current account and overall balance of payments surpluses over the period. External debt falls below 20 percent of GDP and official reserves grow to almost two years of imports by 2007 . Under this scenario, growth remains close to 3.5 percent throughout the period (following a peak in 2004 linked to the coming on stream of investments in the hydrocarbon sector) in spite of an investment rate consistently above 30 percent of GDP. The initial monetary expansion is likely to be reflected in a pick up in inflation.

\section{The financial position of the treasury remains, however, vulnerable to a sharp} and sustained drop in hydrocarbon prices. A sensitivity analysis based on an average price of $\$ 15$ per barrel starting in 2003 indicates that the account of the treasury at the central bank would swing into debit as early as 2004 . The financing need of the treasury would fuel monetary expansion. The balance of payments would not face financing problems throughout the period 2004-07, in spite of the current account deficit, but the stock of external reserves would decrease to a level of about five months of imports in 2007. A drop in the price of hydrocarbons to $\$ 15$ per barrel does not appear to jeopardize the capacity of Algeria to meet its obligations to creditors, including the Fund. ${ }^{6}$ However, the sharp decline in reserves clearly indicates that the balance of payments could not be financed without corrective measures if oil prices remain at that level beyond 2007 .

30. Barring large and sustained shocks, the external position of Algeria will remain strong over the medium term (Table 6). The standardized stress tests for the external debt sustainability reveal that even large and unlikely shocks would not bring the debt ratio above

\footnotetext{
${ }^{6}$ At end-2007, Algeria's obligations to the Fund are projected to amount to less than 2 percent of the quota, while servicing obligations to the Fund in 2007 would represent less than 0.6 percent of export revenues.
} 
the level of 1998 (64 percent of GDP). ${ }^{\top}$ Furthermore, the ratio would return to a declining path after an initial increase accompanying the shocks, suggesting that the external debt is sustainable.

\section{Fiscal Policy}

\section{In 2003 and beyond, the authorities intend to push through their current capital} expenditure program. They expect the level of capital outlays to remain sustained past the ERP horizon of 2004 and well into the medium term, and believe that the reserves accumulated by the treasury at the central bank - together with gross external reservesprovide a sufficient cushion to carry out the expenditure program and finance imports for about 2-3 years in case of a sharp drop in oil prices. In the longer term, they expect to be able to rely on revenues from the projected increase in the exports of gas to sustain expenditure.

\section{The staff expressed concern over the current procyclical fiscal stance. It noted} that, in a period of relatively high oil prices and revenues, the oil stabilization fund, established in 2000, should accumulate financial assets to smooth the longer-term profile of expenditures. The staff stressed that the fiscal stimulus implemented since 2001 had to that point a limited impact on activity and by itself would not generate sustainable growth. Staff also regretted the limited attention paid to costs and benefits in the selection of new investment projects, including those concerning local development. Aside from inflating the size of government in the economy, this expansionary policy increases the vulnerability of government finances to adverse developments in oil prices and may ratchet up recurrent expenditures, thereby complicating macroeconomic management if oil prices were to drop. In addition, long-term considerations would plead for a prudent fiscal policy. ${ }^{\$}$

\footnotetext{
${ }^{7}$ The shocks considered are a two-year consecutive non interest current account deficit corresponding to the historical average minus two standard deviations, or a combination of multiple shocks (slow growth, high interest rates, and a high current account deficit).

${ }^{3}$ Based on curtently plausible assunptions regarding the rate of exploitation of reserves, the long-term price of hydrocarbon products (an assumed long-term price of $\$ 19$ per barrel in real terms) and the real rate of return on investments ( 5 percent in real terms), a rough estimate of the "permanent rent" from hydrocarbons would be of the order of 13-14 percent of GDP in 2001. With nonhydrocarbon revenue of the order of 11 percent of GDP, stabilizing current expenditures below 24-25 percent of GDP would appear consistent with maintaining the level of permanent rent if the government receives a financial retum on its capital investment. (However, if alternative strategies are considered, such as redistributing part of the rent to the public through lower taxation, a reduction of expenditures would be required). This rough estimate indicates that long-term considerations do not call for a significant loosening of the fiscal position achieved in 2001. Furthermore, the inclusion of the quasi-fiscal spending through public banks' financial support of public enterprises and the current low return on government's capital expenditure may call for greater fiscal discipline and an improvement in the quality of public expenditure.
} 
33. Against this background, the staff recommended the adoption of a more conservative fiscal stance. It advised the authorities that the fiscal stimulus should be of limited duration and accompanied by an acceleration of productivity-boosting structural reforms. In particular, expenditures should be reoriented toward financing structural reforms, including by assisting public enterprises to restructure or privatize, and accelerating banking reform. In the short term, it recommended spreading the implementation of new investment projects included in the 2003 Budget Law beyond 2003 and scaling down or canceling projects if oil prices were to fall significantly below projections.

\section{E. Monetary Policy}

34. The authorities reaffirmed their commitment to conduct monetary policy with the objective of maintaining price stability. The staff noted that the liquidity created by the acquisition of foreign assets stemming from hydrocarbon export receipts since early 2000 had been absorbed by the economy without undue pressures on domestic prices and international reserves, but that risks were building up (Box 7). The staff cautioned that economic agents may be unwilling, above a certain level, to hold additional real money balances and would seek alternative outlets for their saving, with attendant risks of higher inflationary pressure, higher dernand for imports of goods and services, capital outflows (including through the paralle] market), and higher asset price inflation in the real estate sector. The staff urged the authorities to step up efforts to accelerate the development of financial markets so as to provide outlets to absorb domestic saving.

35. While welcoming the tightening of the monetary stance through the intraduction of a policy to absorb excess bank liquidity, the staff urged the Bank of Algeria to further improve the implementation procedures of the new instrument (negative liquidity auctions). The staff emphasized the importance of a full absorption of excess bank liquidity, in order to fully satisfy banks' demands for earning assets and to provide them equal access to the facility irrespective of their individual liquidity positions.

36. The staff welcomed the recent improvements in the functioning of the interbank market. However, it recognized the necessity to deepen it and recommended that the Bank of Algeria relinquish its role as a broker in the money market, so that banks can operate freely, while centralizing and disseminating information on concluded transactions. 


\section{Box 7. Would Inflation Pick up in an Environment of High Money Growth?}

Price movements were inconsistent with the relation between money growth and inflation in 2002. Against a background of strong growth of 22 percent in money supply, inflation picked up from 0.3 percent in 2000 to 4.2 percent in 2001 . However, despite the acceleration of money growth during the first half of 2002 (26 percent at an annual rate), surprisingly inflation dropped in the first half of 2002 by 5 percent compared to December 2001.

The money demand has proven to be stable in the long run. An econometric analysis, ${ }^{1}$ carried out over the period 1974-2001 to estimate the long-term money demand equation, shows that a long-run relationship exists between real money balances, output, inflation, and interest rates, where output has a coefficient larger than unity indicating a declining velocity over time.

Excess monetary balances have a strong impact on future inflation. The study also shows that no structural break could be found in the inflation equation during 2000-2001, and the inflation rate continues to adjust to money market disequilibrium. This implies that when money supply exceeds money demand, excess monetary balances will put pressures on prices.

However, several factors exerted downward pressures on prices recently. The 2002 behavior of prices has not followed the money market equilibrium function since several factors have offset the effects of the increase in the money supply, mainly:

- Agricultural output, except for cereals, increased strongly in 2001 and 2002, in part due to the implementation of the National Program for the Development of Agriculture (NPDA), which includes the removal of some regulatory constraints on the crops that can be produced. The relative abundance of agricultural products has reduced food prices, which have a total weight of 44 percent in the Consumer Price Index (CPI).

- The reduction in trade barriers has also relaxed supply constraints in consumption goods. The abolition of minimum duty values and their replacement by a Temporary Additional Duty (TAD) in mid-2001--followed by a reduction of this levy in January 2002-as well as the implementation of a streamlined tariff limited to four rates as of January 2002 have reduced import prices and increased competition between domestic products and imports.

Looking ahead, the continued increase in money growth, however, is likely to generate inflationary pressures. While the above mentioned positive supply shocks have generated a fall in the overall CPI so far, strong money growth fiueled by high hydrocarbon resources and high government spending would sooner or later translate into increased inflation if the government's policy stance remains unchanged. However, in the short term, continued improvements in agricultural output or, in the longer run, implementation of the Association Agreement with the European Union, may dampen inflationary pressures.

${ }^{1}$ See paper on "Money Demand and Monetary Policy: Evidence from Algeria" (forthcoming). 


\section{F. External Policies}

\section{The authorities reaffirmed their commitment to open trade in a framework} consistent with the multilateral trading system. The staff welcomed the authorities' policy intentions and their implementation of the tariff reform. It also encouraged the authorities to avoid ad hoc adjustments in the tariff structure. ${ }^{9}$

\section{The staff argued, however, that the new tariff still implies an anti-export bias,} since the maximum tariff remains relatively high and the number of positions in the category taxed at the highest rate has actually increased. Staff also regretted the extension of the list of goods subject to the TAD to goods that were not protected by the minimum duty values in the past, in violation of the principles used to justify the creation of the TAD. Furthermore, the staff observed that the protection given thereby to locally produced equipment goods is bound to be short-lived since competing goods from the countries of the EU will be allowed duty-free as soon as the AAEU is implemented. This additional protection is likely to reduce the incentive to adjust to competition precisely at a time when such adjustment is becoming urgent.

\section{The authorities confirmed their intention to continue managing the exchange} rate with flexibility to avoid misalignment of the real effective exchange rate. The staff agreed that there is no evidence of misalignment of the exchange rate, ${ }^{10}$ however, it emphasized that heightened uncertainty about the evolution of the equilibrium effective exchange rate calls for greater reliance on the market to determine the exchange rate of the dinar, i.e., a progressive reduction of the discretionary interventions of Bank of Algeria on the interbank foreign exchange market and a deepening of this market. ${ }^{11}$ In order to enhance market determination of the exchange rate, further liberalization of the exchange system is required. First steps would consist of allowing nonhydrocarbon exporters to use freely their foreign exchange earnings; granting banks the freedom to manage - within a sound prudential regulatory framework - their foreign exchange position and the resources mobilized in the form of foreign exchange deposits; and increasing the foreign exchange allocations for various categories of services. When coupled with reforms reducing incentives to operate in the informal sector (customs and tax reforms, modernization of the distribution

\footnotetext{
${ }^{9}$ Tariff dismantling with the EU, under the AAEU, should be accompanied by the teduction of Most Favored Nation (MFN) rate of taxation for similar goods to avoid trade diversion and ease customs administration (by reducing incentives to fraud).

${ }^{10}$ In the nonhydrocarbon sector, new private enterprises are able to export part of their output. However, their competitiveness would be enhanced by tackling the structural deficiencies and institutional weaknesses of the Algerian economy.

"Specifically, the main relevant factors governing the evolution of the equilibrium real effective exchange rate for Algeria are the fluctuations of the terms of trade, the variation of the net foreign assets, tariff reductions (including in the context of bilateral trade agreements such as the AAEU), and evolution of productivity, which would be greatly infiuenced by the pace of structural reforms.
} 
system), such liberalization would greatly contribute to the marginalization of the foreign exchange parallel market. In addition, together with a deepening of the dinar interbank market, it would favor the emergence of a forward foreign exchange market.

40. While acknowledging the achievements of the authorities to reduce the level of the external debt over the years, the staff encouraged them to engage in a more active management of the country's external liabilities, with a view to reducing their cost and lengthening their residual maturity (Chart 4).

Chart 4. Amortization of External Debt Outstanding as of December 31, 2001

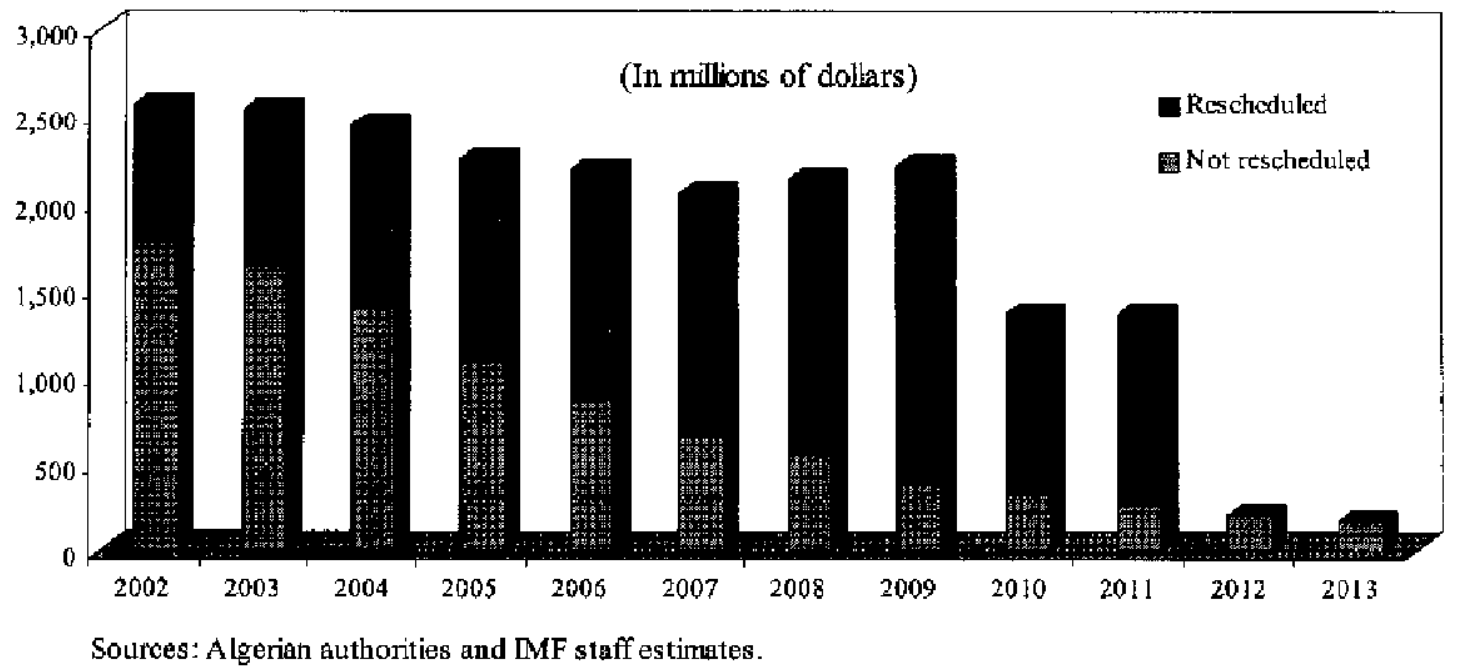

41. The staff encouraged the authorities to follow up on their declared intention to seek a sovereign rating and to work towards achieving appropriate standards for the production and dissemination of statistical information of interest to financial markets. It expressed the readiness of the Fund's International Capital Markets Department (ICM) to provide technical assistance to facilitate Algeria's return to the international capital markets and facilitate the establishment of an investors' relation office. The staff welcomed the agreements with some Paris Club creditors (France, Italy, and Spain) concerning the conversion of eligible debt in equity or development projects. It took note of the authorities' indication that bilateral discussions regarding the debt owed to the Russian Federation had continued in 2002 with the aim of negotiating a mutually acceptable settlement and that there is progress regarding data reconciliation.

42. The staff urged the authorities to grant debt relief to the countries indebted to Algeria that are eligible for debt relief in accordance with the enhanced Heavily Indebted Poor Countries (HIPC) initiative. The authorities stressed that they would consider granting debt relief in amounts at least consistent with those required under the HIPC initiative on a case by casse basis. The staff urged Algeria to consider full participation in the enhanced HIPC initiative and stated that the Fund stands ready to provide Algeria with any technical assistance in this matter. 


\section{G. Private Sector Development and Banking Reform}

\section{The authorities and the staff agreed that, over the medium term, the need to} foster growth and employment requires a reinvigoration of the structural reform effort. The authorities noted, however, that private sector activities have so far remained weak. The staff stressed that, given the large share of GDP already allocated to capital formation, sustained growth calls for a strong improvement in the productivity of the factors of production rather than additional investment expenditures. The staff argued that a better functioning of the institutions underpinning the market could provide an important source of productivity gains and growth. The staff urged the authorities to carefully prioritize public expenditures according to their role in facilitating the acceptance and implementation of the necessary reforms. The illustrative scenario based on this approach results in a progressive acceleration of sustained nonhydrocarbon growth to about 5 percent as early as 2007.

\section{In the staff's view, priority should be given to reducing the size of the public} sector, which remains large and inefficient, and developing an efficient private sector (Box 8). Privatization and restructuring are urgently needed, particularly in the context of the AAEU. While the staff acknowledged and commended the authorities for the considerable preparatory work achieved to date, it expressed concern about the slow progress in effectively implementing privatization and its impact on the credibility of the overall reform process. The staff encouraged the authorities to address this issue in a timely manner through transparent and efficient procedures and in consultation with the trade unions. The staff recommended accompanying the restructuring measures by an extension of the social safety net so as to ease the transition to a more market-based and open economy.

45. To promote Gabor intensive activities and strengthen incentives to operate in the formal sectors, the staff recommended the reduction of various levies assessed on the wage bill. Specifically, the staff supported the ongoing progressive elimination of two wagebased levies and recommended phasing them out by 2005.

\section{Progress in banking sector reform was generally disappointing, notwithstanding} recent measures, including the completion of the financial restructuring of state-owned banks, the initiation of the reform of the payments system, the licensing of new private banks, and the intention to open the capital of one of the six public banks by accepting public bids. The staff underlined that further progress in comprehensive financial sector reform critically depends on clarifying relations between public enterprises and state-owned banks. Therefore, in order to free public banks from non commercial constraints, the staff urged the authorities to ensure that banks are not required any more to provide loans to loss-making public enterprises on a non commercial basis. Such reform, which would entail temporary direct budget financing to loss-making public enterprises in the context of a medium-term plan to restructure the recipient companies, would create an environment conducive to the privatization of public banks. The staff also stressed the urgent need to improve banks' efficiency and management, especiaily in the area of risk assessment, so as to remove current obstacles to the financing of private sector investment. 


\section{Box 8. Private Sector Development}

As a result of liberalization measures adopted in the context of Fund-supported programs, the private sector has developed over the last few years in all activities except hydrocarbon-related construction. As shown in the table below, the private sector represents by far the major driving force of nonhydrocarbon economic activity. Its share in total nonhydrocarbon value added has increased from 66.6 percent in 1993 to 78 percent in 2000 . In addition to the oil sector and hydrocarbon-related construction, the public sector remains the main player in industry (about 65 percent of value added in 2000, down from about 84 percent in 1993). But even there, the private sector is developing rapidly (about $6-8$ percent per year in real terms). ${ }^{1}$ Implementation of the government's privatization program should accelerate this trend. Private banks, albeit small in size, are also developing rapidly, which should help facilitate the financing of the private sector and its further expansion.

Share of the Private Sector in Value Added

(In percent of total value added in each sector)

\begin{tabular}{lrr}
\hline & 1993 & 2000 \\
\hline Agriculture & 99.0 & 99.5 \\
Hydrocarbon & 0.0 & 5.0 \\
Hydrocarbon-related construction & 0.0 & 0.0 \\
Industry (excluding hydrocarbon) & 15.7 & 35.0 \\
Construction (nonrelated to hydrocarbon) & 60.6 & 67.9 \\
Transportation and telecommunications & 56.2 & 72.3 \\
Retail trade & 84.8 & 96.9 \\
Services $_{\text {Total including hydrocarbon }}^{2}$ & 84.3 & 89.3 \\
Total excluding hydrocarbon $^{-}$ & 47.7 & 42.2 \\
\hline
\end{tabular}

Source: Algerian authorities

Distribution of Value Added, Excluding Hydrocarbon
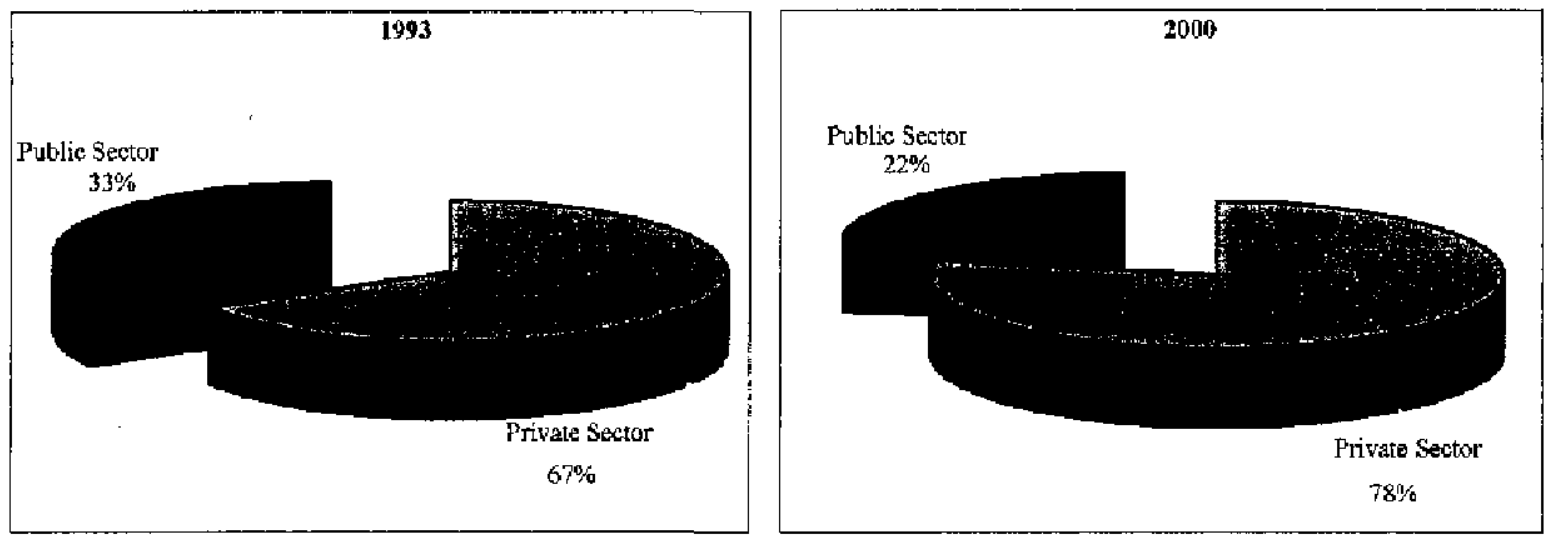

${ }^{1}$ The fastest development can be seen particularly in the food processing, textile, and pharnaceutical sectors.

${ }^{2}$ Because the share of hydrocarbon, which is mainly state-owned, in the value added increased strongly between 1993 and 2000, the share of the private sector in total value added (including hydrocarbon) decreased during the same period. 


\section{The staff commended the authorities for their efforts at reinforcing bank}

supervision but stressed the need for further improvements and urged them to ensure banks' compliance with all banking regulations - including those pertaining to prudential ratios such as capital adequacy - and the timely transmission of detailed balance sheets and all other required financial data to the relevant departments of the central bank, subject to financial penalties for noncompliance. The authorities and the staff agreed that the joint Fund-Bank Financial Sector Assessment Program (FSAP) mission scheduled for March 2003 would review in depth the performance of the financial system and the requirements for its development.

\section{H. Governance, Data, and Other Issues}

\section{A lack of rigor in the management of economic institutions is hampering} investment and growth in Algeria. The staff commended the authorities for the progress achieved in a number of transparency and governance issues-in particular the strengthening of tax and customs administrations and the adoption, in consultation with the World Bank, of a revised procurement code. It welcomed the authorities' request for a fiscal Report on the Observance of Standards and Codes (ROSC) mission and their provision of responses to the preliminary questionnaire. Nevertheless, a number of serious weaknesses remain. In particular, the government needs to: (a) reduce its intervention in the economy (through inter alia privatization, banking reform, and land reform); (b) increase transparency and accountability, (including at the local and regional level) with, in particular, the strengthening of the independence and effectiveness of institutions in charge of investigating financial abuses and misappropriations; and (c) promote a rule-based environment (through judicial and legal reforms, including measures to strengthen the independence and efficiency of the judicial system). It also recommended establishing, with the Fund and World Bank assistance, an investors' council that would work on improving Algeria's business climate.

49. On anti-money laundering (AML), the authorities adopted the legal operating framework of the Financial Intelligence Unit (FIU) in the 2003 Budget Law. The staff wetcomed the authorities" response to the questionnaire on "Anti-Money Laundering and Combating the Financing for Terrorism Policies and Institutions." Together with the establishment of the FIU and the preparation of legislation on AML, the questionnaire will be discussed in detail during the forthcoming FSAP mission.

50. Technical assistance. The authorities expressed their satisfaction with the tax and customs administration reforms implemented so far with Fund assistance, particularly the establishment of the large taxpayers unit and the pilot centralized tax unit. They called for the continuation and intensification of Fund support to implement the remaining technical assistance recommendations. They also confirmed their interest in receiving technical assistance in a number of areas, including access to financial markets, safeguards assessments, and banking and insurance supervision.

51. Algeria's statistical system needs to be substantially improved to strengthen the monitoring of economic conditions, the formulation of economic policies, and Fund 
surveillance. The multisector statistics mission of September 2002 confirmed that-while the basic infrastructure for a sound statistical system is largely in place and local staff are generally well trained and experienced - substantial weaknesses still prevail in many areas, particularly in data dissemination and timeliness, but also in data coverage, poor or non existent source data, periodicity, and methodology. ${ }^{2}$

\section{The authorities favor the principle of subscribing to the Special Data}

Dissemination System (SDDS). In order to reach this objective, they have agreed with the multisector statistics mission on an action plan.

\section{The staff urged the authorities to: (a) substantially strengthen data coverage,} quality, and timeliness; (b) allocate sufficient resources for the compilation of statistics; (c) allow the publication of currently avaitable but unpublished studies; and (d) report data to the Fund as soon as they become available to allow for adequate surveillance. The staff also urged early implementation of the above-mentioned action plan.

\section{STAFF APPRAISAL}

\section{After restoring-under particularly difficult circumstances-macroeconomic} stability with Fund support, Algeria adopted a conservative macroeconomic policy stance in 1999-2000. This prudent fiscal stance, coupled with high oil revenues and a gradual easing in monetary conditions, was reflected in a major strengthening of the balance of payments position. This conservative policy also translated into an improvement in the external debt indicators and contributed to a marked decline in the inflation rate.

\section{Faced with mounting social demands, and in the context of large treasury} deposits accumulated at the central bank, the government decided to resort to a more expansionary fiscal policy from 2001 until private activity generates sufficient employment opportunities. It adopted a major fiscal stimulus plan (ERP) covering the 200104 period and substantially raised civil service wages in early 2001. Furthermore, all Budget Laws since 2001 have been marked by a jump in the amounts appropriated for capital expenditure. Overall, this sizable fiscal easing is likely to have resulted in the reemergence of a small budget deficit from 2002 , despite prevailing high hydrocarbon revenues.

\section{The staff acknowledges that the loosening of the fiscal policy stance undertaken} by the government will endanger neither the external nor the treasury positions as long as oil prices remain high. Indeed, the treasury has accumulated a large cushion of deposits

\footnotetext{
${ }^{12}$ In particular, while progress has been recorded in the coverage of the monetary and banking statistics, long lags in their compilation are still prevalent and hinder monetary policy analysis and banking supervision. Fiscal data are also compiled with a substantial lag and are of unequal quality. The current CPI is based on a consumption basket dating back to 1988 , before price liberalization and structural changes deeply altered the consumption structure. Data on priority policy areas for the government--such as the labor market, income distribution, or the development of the private sector-remain scarce, outdated, or unavailable.
} 
at the Bank of Algeria that would cover budget financing needs for well over a year following a pronounced downturn in oil prices. The balance of payments would be financed over an even longer period. Similarly, the staff recognizes that populations in rural areas have started benefiting from improved public infrastructure and that the ERP has boosted investment in agriculture and residential housing.

57. Nevertheless, the staff is concerned about an increased policy reliance on fiscal expansion to boost growth. It considers that the continued fiscal expansion will only temporarily and modestly boost growth performance. In addition, it increases the size of the government in the economy and raises issues related to procyclicality, quality of investment projects, and intergenerational equity. Staff is of the view that sustainable higher growth can only result from productivity-boosting structural reforms and that expenditures should be prioritized and reoriented to ease the fiscal burden of such reforms.

\section{Furthermore, a sizable fiscal expansion increases the budget's vulnerability to} adverse developments in the oil market and weakens the purpose of the stabilization fund. As oil prices may turn out to be lower than envisaged in the baseline scenario, the staff urges the authorities to cautiously manage expenditure on new investment projects in 2003 and to consider a gradual tightening of the macroeconomic policy stance if oil prices were to decline substantially and durably.

\section{The staff is also concerned by the possible resumption of inflation that fiscal} easing could generate. While noting Algeria's good inflation performance in 2002 owing mainly to lower food prices, the staff is concerned about the negative impact that the new macroeconomic stance could have on Algeria's inflation performance. It urges the authorities to maintain a cautious monetary stance and is reassured by their resolve to devote monetary policy to the maintenance of low inflation. The staff also recommended introducing new instruments that would deepen the financial markets.

60. The authorities' continued commitment to implementing the managed float exchange rate regime in a nexible way seems appropriate to absorb the external shocks that Algeria's economy faces periodically. The staff agrees that there is no evidence of exchange rate misalignment; however, it recommends that the exchange system be further liberalized to strengthen the role of market forces in determining the exchange rate and contribute to reducing the importance of the parallel market further. The staff also supports a more active management of external liabilities aimed at reducing debt service and extending the maturity of external debt. It welcomes the reported contacts between the Algerian and Russian authorities and encourages an early settlement of bilateral debt issues. While welcoming the authorities' intention to grant debt relief on a case by case basis to HIPC eligible countries, staff urges Algeria to consider full participation in the enhanced HIPC initiative.

61. Despite its recent achievements in terms of stability, Algeria still faces major challenges over the medium term. While preserving stability, it needs to improve real growth performance to allow for a reduction in unemployment and a rise in standards of living. 
This requires the completion of the transition toward a fully effective market-based economy and the introduction of a comprehensive set of reforms to (a) drastically strengthen and raise the efficiency of the banking system in the allocation of resources toward productive activities; (b) privatize/restructure the public enterprises while replacing the current flow of directed credit received from banks with a direct and temporary budget subsidy, as a transitional measure; and (c) improve the allocation of resources through enhanced competition and further opening of the economy. In addition, security and social peace have to be consolidated further to reinforce the investment climate and address the social issues facing the country.

\section{The staff welcomes the authorities' intention to accelerate the pace of structural} reforms. Nevertheless, while effective progress was achieved in the summer of 2001 , the staff notes that, since then, reform efforts have largely stalled. It welcomes the government's assurances that its recovery plan is not a substitute for much needed structural reforms and its intention to accelerate privatization. Nevertheless, the staff is concerned about the slow pace of reform and notes that the social and political constraints that may have contributed to it are still prevalent. The staff calls on the government to further accelerate the pace of privatization and public sector restructuring, along with banking sector reform. It also urges the government to implement privatization in the most transparent manner and in consultation with trade unions. It suggests that an enhanced social safety net would cushion the impact of public sector restructuring in the event of labor retrenchment. Institutional reforms, such as agricultural land and judicial reforms, also need to be promptly implemented.

63. The staff welcomes the government's implementation of a comprehensive tariff reform in 2001-02, the signature of the $A A E U$, and the resumption of negotiations towards Algeria's accession to the WTO. The government should be commended for trade liberalization measures taken in 2001-02. However, the staff is concerned about the adoption of an excessively large list of goods submitted to the TAD replacing the minimum duty values. It strongly encourages the government to further reduce the tariff rates in the context of the implementation of the AAEU.

64. The staff welcomes ongoing efforts to improve statisties and the authorities' interest in the Fund's SDDS as a framework for statistics development; however, it is concerned that persistent data weaknesses in major areas continue to hamper the monitoring of economic conditions and formulation of economic policies. The staff urges the authorities to substantially strengthen data coverage, quality, timeliness, and dissemination. Although systematic and timely transmission of data would also facilitate the Fund's surveillance activities, the provision of data to the Fund is viewed by the staff as generally adequate for effective surveillance.

\section{The staff commends the authorities for their increased willingness to foster} transparency and urges them to drastically improve governance. The publication of the 2000 and 2001 Article IV staff reports, the reform of the tax and customs administrations, the willingness to reduce government intervention in the economy and to promote a rule-based competitive environment are positive signs. Nevertheless, efforts to improve governance, including at the local and regional levels, need to be substantially strengthened. 
66. The staff welcomes the authorities' intention to maintain a close policy dialogue with the Fund and to continue implementing recommendations made by recent technical assistance missions. This should help safeguard the progress achieved since the mid-1990s and encourage further policy reforms in the upcoming period.

67. It is proposed that the next Article IV consultation with Algeria take place on the standard 12-month cycle. 
Table 1. Algeria: Selected Economic and Financial Indicators, 1998-2003

\begin{tabular}{|c|c|c|c|c|c|c|}
\hline & \multirow[b]{2}{*}{1998} & \multirow[b]{2}{*}{1999} & \multirow[b]{2}{*}{2000} & \multirow{2}{*}{$\frac{\text { Est. }}{2001}$} & \multicolumn{2}{|c|}{ Projections } \\
\hline & & & & & 2002 & $\overline{2003}$ \\
\hline & \multicolumn{6}{|c|}{ (Annual percentage change) } \\
\hline \multicolumn{7}{|l|}{ National income and prices } \\
\hline GDP at constant prices & 5.1 & 3.2 & 2.4 & 2.1 & 2.3 & 3.5 \\
\hline Hydrocarbon sector & 4.0 & 6.2 & 4.9 & -1.6 & 0.5 & 2.0 \\
\hline Other sectors & 5.5 & 2.2 & 1.5 & 4.5 & 3.0 & 4,0 \\
\hline Nonhydrocarbon, nonagriculture sector & 4.4 & 2.2 & 2.8 & 3.1 & 3.8 & 3,9 \\
\hline GDP deflator & -3.8 & 10.9 & 23.9 & 1.4 & -1.2 & 4.9 \\
\hline Hydrocarbon & -24.8 & 26.7 & 76.7 & -6.2 & -2.9 & 7.2 \\
\hline Nonhydrocarbon & 6.1 & 4.7 & 4.0 & 60 & 0.1 & 4.0 \\
\hline Consumer price index (average) & 5.0 & 2.6 & 0.3 & 4.2 & 1.4 & 4.2 \\
\hline \multicolumn{7}{|l|}{ External sector $1 /$} \\
\hline \multirow[t]{2}{*}{ Exports, fo.b. } & -26.6 & $2 \mathrm{~L} .5$ & 75.7 & -11.8 & -5.2 & 10.2 \\
\hline & \multicolumn{6}{|c|}{ (Changes as a percent of beginning money stock M2) } \\
\hline \multicolumn{7}{|l|}{ Money and eredit } \\
\hline Net foreign assets & -6.4 & -7.0 & 33.9 & 26.4 & 14.7 & 12.7 \\
\hline Domestic credit & 42.9 & 23.2 & -18.3 & -1.2 & 5.7 & 3.4 \\
\hline Credit to the government (net) $2 /$ & 27.7 & 7.8 & -9.5 & -5.3 & 2.2 & 0.2 \\
\hline Credit to the economy $2 /$ & 15.2 & 15.4 & -8.8 & 4.2 & 3.5 & 3,2 \\
\hline Money and quasi-money & 47.2 & 12.4 & 13.0 & 22.3 & 17.4 & 16.0 \\
\hline \multirow[t]{2}{*}{ Liquidity ratio (M2/nonhydrocarbon GDP) } & 73.3 & 77.0 & 82.4 & 90.8 & 103.5 & 110,9 \\
\hline & \multicolumn{6}{|c|}{ (In percent of GDP) } \\
\hline \multicolumn{7}{|l|}{ Central govemment finance } \\
\hline Overall budget balance (deficit-) & -3.8 & -0.5 & 9.8 & 3.4 & -0.9 & -1.6 \\
\hline Revenue & 27.6 & 29.6 & 38.7 & 35.0 & 35.0 & 34.4 \\
\hline Of which: hydrocarbons $3 /$ & 15.2 & 18.3 & 29.7 & 24.1 & 22.6 & 23.3 \\
\hline Of which nonhydrocarbons & 12.4 & 11.1 & 8.9 & 10.9 & 12.3 & 11.0 \\
\hline Expenditure 4 & 31.4 & 30.1 & 28,9 & 31,6 & 35.9 & 35.9 \\
\hline Of which curent expenditure & 23.6 & 24.1 & 21.0 & 22.8 & 23.9 & 23.7 \\
\hline \multirow[t]{2}{*}{ of which investment } & 7.5 & 5,8 & 7.9 & 8.5 & 11.1 & 11.6 \\
\hline & \multicolumn{6}{|c|}{ (In billions of U.S. dollars; unless otherwise specifled) } \\
\hline \multicolumn{7}{|l|}{ External sector } \\
\hline Exports, fo.b. & 10.1 & 12.3 & 21.7 & 19.1 & 18.1 & 20.0 \\
\hline Of which: hydrocarbons & 9,8 & 11.9 & 21.1 & 18.5 & 17.5 & 19.3 \\
\hline Imports, fo.b. & 8.6 & 9.0 & 9.3 & 9.5 & 10.8 & 11.7 \\
\hline Interest payments & 2.0 & 1,9 & 1.7 & 1.5 & 1.2 & 1.1 \\
\hline Current account (deficit -) & -0.9 & 0.0 & 9.1 & 7.1 & 4.3 & 4.7 \\
\hline Overall balance (deficit -) & -1.7 & -2.4 & 7.6 & 6.2 & 3,5 & 4.8 \\
\hline Gross official reserves (end-period) & 6.8 & 4.4 & 11.9 & 18.0 & 22.5 & 26.8 \\
\hline External current account (in percent of GDP) & -1.9 & 0.0 & 16.9 & 12.9 & 8.1 & 8.1 \\
\hline Extemal debt & 30.5 & 28.3 & 25.3 & 22.6 & 21.9 & 20.2 \\
\hline External debt (in percent of GDP) & 64.3 & 58.6 & 46.6 & 41.3 & 40.9 & 34.4 \\
\hline Real effective exchrige rate 5/ & 4.8 & -7.9 & -2.5 & 2.8 & $\ldots$ & $\ldots$ \\
\hline
\end{tabular}

Sources: Algerian authorities; and MF staff estimates and projections.

1/ In U.S. dollars terms.

2/ Including the impact of financial restructuring package involving the swap of govemment bonds forr public enterpises' commercial debt.

$3 /$ Including dividends on current profits paid by sonatrach.

$4 /$ Including special accounts and net lending.

5/ Annual average changes in total trade--weighted INS index. A decrease in the index implies a depreciation. 
Table 2. Algeria: Summary of Central Government Operations, 1998-2003

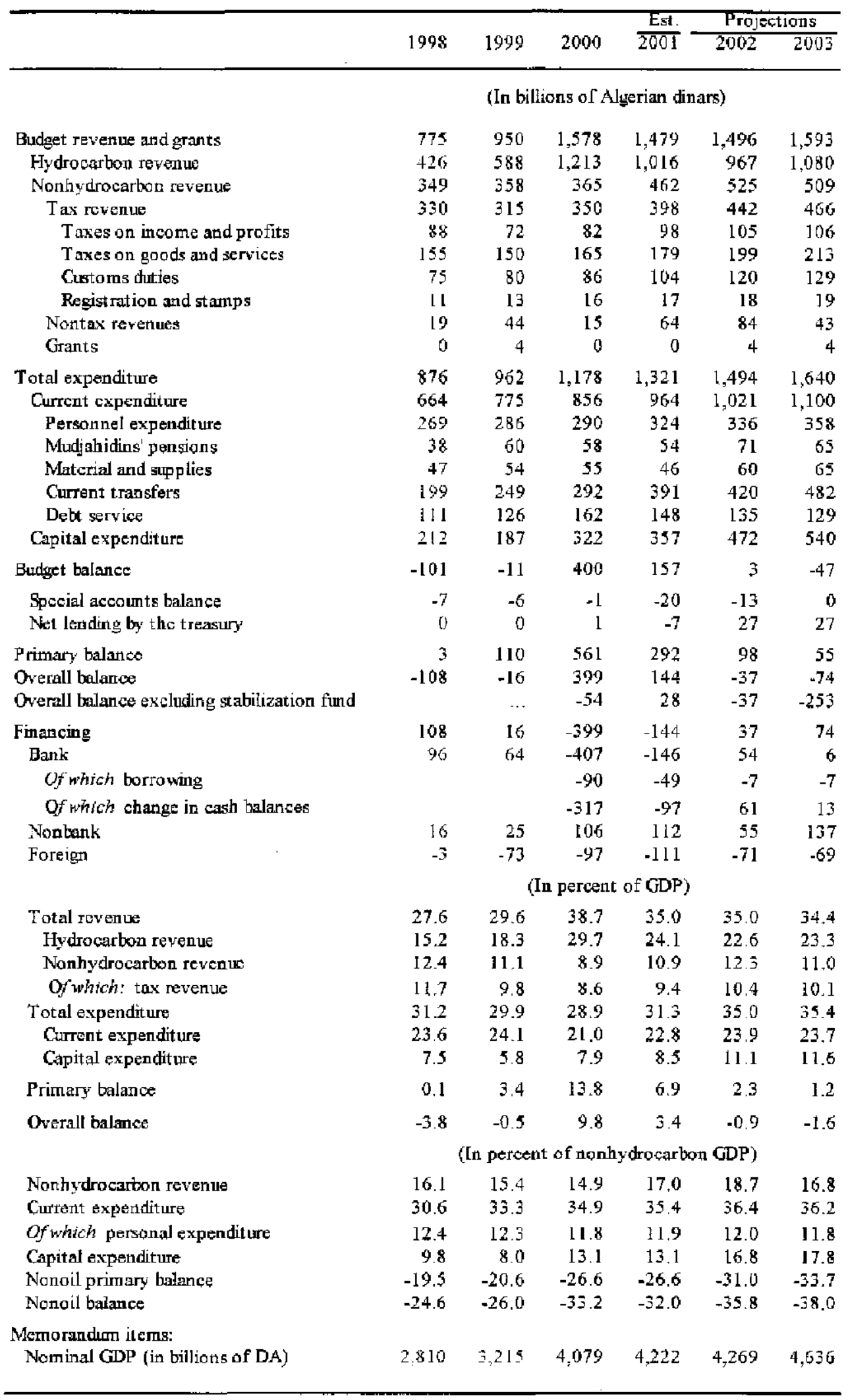

Sources: Da a provided by thc authorities; and IMF staff est imates and projections. 
Table 3. Algeria: Monetary Survey, 1998-2003

\begin{tabular}{|c|c|c|c|c|c|c|}
\hline & \multirow[b]{2}{*}{1998} & \multirow[b]{2}{*}{1999} & \multirow[b]{2}{*}{2000} & \multirow{2}{*}{$\frac{\text { Est. }}{2001}$} & \multicolumn{2}{|c|}{ Projections } \\
\hline & & & & & 2002 & 2003 \\
\hline & \multicolumn{6}{|c|}{ (In billions of Algerian dinars; at end of the period) } \\
\hline Foreign assets (net) & 281 & 170 & 776 & $1,31 \mathrm{I}$ & 1,675 & 2,046 \\
\hline Foreign assets (BA) & 423 & 330 & 919 & 1,446 & 1,798 & 2,137 \\
\hline Foreign liabilities (BA) & 145 & 157 & 145 & 132 & 119 & 88 \\
\hline Foreign assets (comm. banks) & 28 & 28 & 28 & 32 & 33 & 33 \\
\hline Foreign liabilities (comm. banks) & 25 & 31 & 27 & 35 & 36 & 36 \\
\hline Net domestic assets & 1,312 & 1,620 & 1,247 & 1,163 & 1,229 & 1,323 \\
\hline Dom estic credit & 1,629 & 1,999 & 1,671 & 1,648 & 1,788 & 1,887 \\
\hline Credit to government (net) $1 /$ & 723 & 848 & 678 & 570 & 624 & 629 \\
\hline Credit to the economy $1 /$ & 906 & 1,151 & 994 & 1,078 & 1,164 & 1,257 \\
\hline Other items net $2 /$ & -318 & -379 & -425 & -485 & -559 & -563 \\
\hline Money and quasi-money (M2) & 1,593 & 1,789 & 2,023 & 2,474 & 2,904 & 3,369 \\
\hline Money & 826 & 905 & 1,048 & 1,239 & 1,454 & 1,687 \\
\hline \multirow[t]{2}{*}{ Quasi-money } & 766 & 884 & 974 & I,235 & 1,450 & 1,682 \\
\hline & \multicolumn{6}{|c|}{ (Percent change over 12 -month period) $3 i$} \\
\hline $\begin{array}{l}\text { Money and quasi-money (M2) } \\
\text { Of which }\end{array}$ & $\ldots$ & 12.4 & 13.0 & 22.3 & 17.4 & 16.0 \\
\hline Money & $\ldots$ & 9.5 & 15.8 & 18.2 & 17.4 & 16.0 \\
\hline Net domestic assets (banking system) & $\ldots$ & 23.5 & -23.0 & -6.7 & 5.7 & 7.7 \\
\hline \multirow[t]{2}{*}{ Credit to the economy } & $\ldots$ & 27.0 & -13.6 & 8.5 & 8.0 & 8.0 \\
\hline & \multicolumn{6}{|c|}{ (Changes as a percent of beginning money stock) } \\
\hline Money and quasi-money (M2) & $\ldots$ & 12.4 & 13.0 & 22.3 & 17.4 & 16.0 \\
\hline Foreign assets & $\ldots$ & -7.0 & 33.9 & 26.4 & 14.7 & 12.7 \\
\hline Net domestic assets & $\ldots$ & 19.3 & -20.9 & -4.1 & 2.7 & 3.3 \\
\hline Dom estic credit & $\ldots$ & 23.2 & -18.3 & -1.2 & 5.7 & 3.4 \\
\hline Net credit to government & $\ldots$ & 7.8 & -9.5 & -5.3 & 2.2 & 0.2 \\
\hline Credit to the economy & $\ldots$ & 15.4 & -8.8 & 4.2 & 3.5 & 3.2 \\
\hline \multicolumn{7}{|l|}{ Memorandum items: } \\
\hline Liquidity ratio (e.o.p. M2/GDP) & 56.7 & 55.7 & 49.6 & 58.6 & 68,0 & 72.7 \\
\hline Liquidity ratio (e.o.p. M2/NH GDP) & 73.3 & 77.0 & 82.4 & 90.8 & 103,5 & 110.9 \\
\hline Domestic credit/GDP & 58.0 & 62.2 & 41.0 & 39,0 & 41.9 & 40.7 \\
\hline Net credit to government/GDP & 25.7 & 26.4 & 16.6 & 13.5 & 14.6 & 13.6 \\
\hline Credit to the economy/GDP & 32.2 & 35.8 & 24.4 & 25.5 & 27.3 & 27.1 \\
\hline Credit to the economy/NH GDP & 41.7 & 49.5 & 40.5 & 39.6 & 41.5 & 41,4 \\
\hline Nominal GDP in billions of DA & 2,810 & 3,215 & 4,079 & 4,222 & 4,269 & 4,636 \\
\hline Nominal NH GDP in billions of DA & 2,172 & 2,324 & 2,454 & 2,723 & 2,806 & 3,036 \\
\hline Exchange rate (e.o.p.) & 60.4 & 69.3 & 75.3 & 77.8 & - & -. \\
\hline
\end{tabular}

Sources: Bank of Algeria; and Fund staff projections.

1/ This includes the impact of banks' restructuring packages. The conversion of banks'claims on public enterprises in banks' claims on the government resulted, other things being equal, in a decrease of credit to the economy and an equal increase in credit to the government in 2000 and 2001.

2/ This includes the debt-rescheduling proceeds blocked in special accounts at the Bank of Algeria.

3 / Starting in 1998 coverage of monetary data have been extended to include saving banks 
Table 4. Algeria: Balance of Payments, 1998-2003

(In billions of U.S. dullärs; unless otherwise indicated)

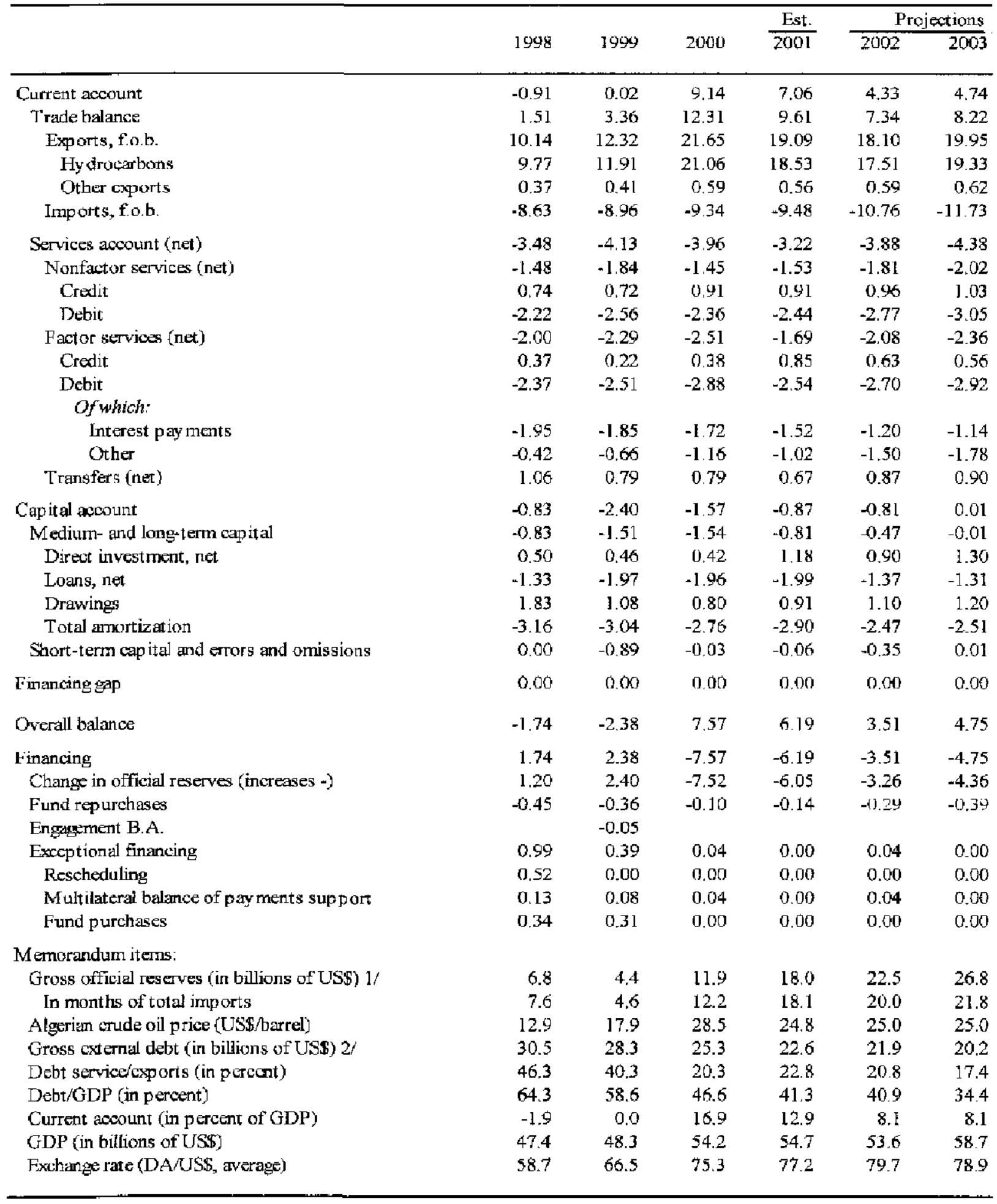

Sources: Bank of Algeria (through 2001 data); and Fund staff projections.

$1 /$ According to the information provided by the Bank of Algeria, all official reserves are liquid.

2/ According to the Bank of Algeria, its actual dat a include short-term debt, use of Fund resources, and debt to Russia. 
Table 5. Algeria: Illustrative Mediurn-Term Scenarios, 2001-07

\begin{tabular}{|c|c|c|c|c|c|c|c|c|c|c|c|c|c|c|c|c|c|}
\hline & \multirow[b]{2}{*}{2001} & \multirow{2}{*}{$\frac{\text { Proj. }}{2002}$} & \multicolumn{5}{|c|}{$\begin{array}{l}\text { Soenario Bised on WEO Oil Priecs } \\
\text { Slow Struetural Adjustment }\end{array}$} & \multicolumn{5}{|c|}{$\begin{array}{l}\text { Scenario Bused on WEO Oil Prices } \\
\text { Rapid Structural Adjustment }\end{array}$} & \multicolumn{5}{|c|}{$\begin{array}{c}\text { Secnario with L Lw oil Prices } \\
\text { Projection }\end{array}$} \\
\hline & & & 2003 & 20004 & 2005 & 2006 & $2(x) 7$ & 2003 & 2004 & 2005 & 2006 & 2007 & 2003 & 2004 & 2005 & 2006 & 2007 \\
\hline \multicolumn{18}{|l|}{ Main assumption } \\
\hline Oil prices (US\$ per bamel) & 24,8 & 25.0 & 250 & 22.5 & $22.1)$ & 21.0 & 21.0 & 25.0 & 225 & 22.0 & 21.0 & 21.0 & 15.0 & 15.0 & 15.0 & 15.0 & 150 \\
\hline Hydroearbon GDP (volume change) & -1.6 & 0.5 & 2.0 & 6.3 & 2.9 & 2.8 & 2.9 & 2.0 & 6.3 & 2.9 & 2.8 & 2.9 & 2.0 & 6.3 & 2.9 & 2.8 & 2.9 \\
\hline \multicolumn{18}{|l|}{ Selected economic and financial irulicutors } \\
\hline Real GDP (in porcentage chrange) & 2.1 & 2.3 & 3.5 & 4.3 & 3.5 & 3.6 & 3.6 & 3.5 & 4.3 & 3.7 & 4.0 & 4.4 & 3.5 & 4.3 & 3.5 & 3.6 & 3.6 \\
\hline Nonhydraearbos GDP (in percentage change) & 4.5 & 2.9 & 4.0 & 3.6 & 3.7 & 3.8 & 3.9 & 4.0 & 3.7 & 4.0 & 4.4 & 4.9 & 40 & 3.6 & 3.7 & 3.8 & 3.9 \\
\hline CPI inllelion (in percent, averaje) & 42 & 1.4 & 4.2 & 4.0 & 4.2 & 4.3 & 4,3 & 4.2 & 4.0 & 4.1 & 3.9 & 3.5 & $4: 2$ & 4.0 & 4.2 & 4.3 & 4.3 \\
\hline Monetary expunsion (M2, in percentage cheinge) & 22.3 & 17.4 & 16.0 & 11,0 & 10.4 & 7.9 & 7.6 & 16.0 & 10.8 & 10.3 & 7.5 & 6.8 & 130 & 7.4 & 7.6 & 5.6 & 5.8 \\
\hline Net viedil to the gavernment (in percent of GDP) & 1.3 .5 & 14.6 & 13.6 & 13.4 & 13.8 & 14.2 & 13.9 & 13.6 & 13.3 & 13.6 & 13.6 & 12.8 & 23.1 & 29.9 & 36.3 & 41.3 & 45.6 \\
\hline Credit to the exonomy (in percent of (GDP) & 25.5 & 27.3 & 24.1 & 28.1 & 28.6 & 29.2 & 29.5 & 27.1 & 28.1 & 28.6 & 29.3 & 29.7 & 30.7 & 31.4 & 31.6 & 31.9 & 32.1 \\
\hline Liquidity ratic) (M2/nsmlyddrocarbon GDl') & 90.8 & 109.5 & 110.9 & 114.1 & 116.3 & 115.9 & 115.0 & [ 10.9 & 1139 & 115.8 & 114.7 & 132.6 & 108.8 & 108.6 & lor. 9 & 105.2 & 102.5 \\
\hline Ovaral| budget balance (in percent of GDP) & 3.4 & -0.9 & -1.6 & -1.3 & -1.2 & -1.3 & -0.9 & -1.6 & -1.2 & -1.0 & -1]$. & -0.4 & $-9,6$ & .8 .9 & -8.4 & -7.8 & -7.5 \\
\hline Hydrecatbon revenues (in porcent of GDP) & 24.1 & 22.6 & 23.3 & 22.4 & 21.5 & 20.5 & 20.0 & 23.3 & 22.4 & 21.5 & 20.4 & 9.7 & 18.6 & 18.1 & 17.5 & 17.0 & 16.6 \\
\hline Nonbydrocarton revenues (in pereent of GDP') & 10.9 & 12,3 & 11.0 & 11.6 & 12,0 & 12.4 & 12.5 & 11.0 & 11.7 & 12.0 & 12.4 & 12.5 & 124 & 12.7 & 12.6 & 12.5 & 123 \\
\hline Fxpenditure (in percenl of GDP) & 31.6 & 35.9 & 36.0 & 35.4 & 34.8 & 34.3 & 33.5 & 360 & 35.3 & 34.6 & 33.9 & 32.7 & 40.7 & 39.7 & 38.6 & 37.4 & 36.5 \\
\hline Hydrexeabun Tixports (in Trittions of USS) & 18.5 & 17.5 & 193 & 18.4 & 18.5 & 18.2 & 18.7 & 19.3 & 18.4 & 18.5 & 18.2 & 18.7 & 13.0 & 12.6 & 13.0 & 13.3 & 13.7 \\
\hline Imports, fob. (in billions ol"US\$) & 9.5 & 10.8 & 11.7 & 12.4 & 13.1 & 13.9 & 14.7 & 11.7 & 12.4 & 13.1 & 14.0 & 14.8 & 11.7 & 12.6 & 13.2 & 13.9 & 146 \\
\hline Externul current aceoum (in pereent of GDP) & 12.9 & 8.] & 8.1 & 5.4 & 4.8 & 3.3 & 2.9 & $\$ .1$ & $\$ .4$ & 4.8 & 3.2 & 2.6 & -1.6 & -4.2 & -4.4 & -5.0 & -5.5 \\
\hline Internutiont reserves (in biltions of US\$) & 18.0 & 22.5 & 26.8 & 29.4 & 31.5 & 32.9 & 34.4 & 26.8 & 29.4 & 31.5 & 32.8 & 34.2 & 21.7 & $\$ 8.8$ & 15.4 & 11.5 & 7.7 \\
\hline In montbs of imports & 18.1 & 200 & 21.8 & 22.6 & 22.9 & 22.5 & 22.4 & 21.8 & 22.6 & 22.9 & 22.4 & 22.1 & 17.7 & 14.2 & 11.1 & 7.9 & 50 \\
\hline in prrcent of shart-term debt $2 /$ & 593.6 & 743.4 & 886.0 & 971.3 & $1,042.5$ & $1,086.1$ & $1,138.3$ & 886.0 & 971.2 & $1,041.8$ & $1,083.7$ & $1,131.3$ & 718.4 & 620.0 & 508.1 & 380.4 & 254.1 \\
\hline Fixternal debt service (as pescentago of axporth of $G \& S$ ) & 22.8 & 20.7 & 17.3 & 18.3 & 17.9 & 18.2 & 15.3 & 17.3 & 18.3 & 17.4 & 18.2 & 15.3 & 24.8 & 25.8 & 24.7 & 24.2 & 20.4 \\
\hline Tixtemal deht (in percent of GLP) & 41.3 & 40.9 & 34.4 & 30.8 & 26.5 & 22.6 & 19.2 & 34.4 & 30.8 & 26.4 & 22.4 & 18.9 & 39,0 & 34.6 & 29.5 & 24.7 & 21.0 \\
\hline National savings (in penent of GDP) & 39.6 & 39.0 & 390 & 36.7 & 35.9 & 34.7 & 34.4 & 39.0 & 37.0 & 36.7 & 35.3 & 35.1 & 39.4 & 30.7 & 30.0 & 29.2 & 28.8 \\
\hline Govermment & 1179 & 10.2 & 10.1 & 10.1 & 9.9 & 9.4 & 9.6 & 10.1 & {$[0]$.} & 9.9 & 9.4 & 9.5 & 3.6 & 3.9 & 3.8 & 3.9 & 3.9 \\
\hline Nongovernmenl & 27.7 & 28.8 & 290 & 26,6 & 26.6 & 25.3 & 24.8 & 29.0 & 26.9 & 26.9 & 25.8 & 25.5 & 29.8 & 26.8 & 26.1 & 25.2 & 24.8 \\
\hline Irvestmen1 (in percenl of GDP) & 26.7 & 30.9 & 30.9 & 31.3 & 31.1 & 31.4 & .31 .5 & 30.9 & 31.6 & 32.0 & 32.] & 32.4 & 350 & 34.9 & 34.4 & 34.2 & 34.2 \\
\hline Goverument & 8.5 & 11.] & 11.6 & 11.4 & 110 & 10.8 & 10.5 & 11.6 & 11.3 & 10.9 & 10.5 & 9.9 & 13.2 & 12.8 & 12.2 & 11.8 & 11.5 \\
\hline Nongovetnment & 18.2 & 19.8 & 19.3 & 19.9 & 20.1 & 20.7 & 21.0 & 19.3 & 20.9 & 21.0 & 21.6 & 22.5 & 21.8 & 22.1 & 22.1 & 22.4 & 22.8 \\
\hline
\end{tabular}

Snurces: Algarian authorities; and IMF staff estimates und projotions.

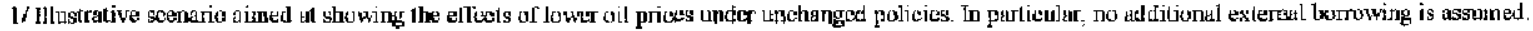

2/On the basis of temaining indurities. 
Table 6. Algeria: External Debt Sustainability Framework, 1997-2007

(In percent of GDP, unless otherwise indicated)

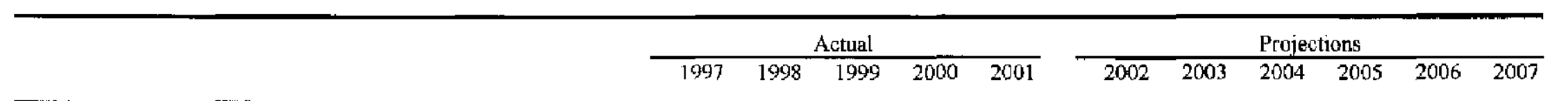

\section{External deb}

Change in external debt

Identified external debt-creating flows $(4+8+11)$

Current account deficit, excluding interest payments

Deficit in balance of goods and services

Exports

Imports

Net non debt creating capital inflows (negative)

Net foreign direct investment, equity

Net portfolio investment, equity

Autonatic debt dynamics l/

Contribution from nominal interest rate

Contribution from real GDP growth

Contribution from price and exchange rate changes $2 /$

Residual, including change in gross foreign assets (2-3)

External debt-to-exports ratio (in percent)

Gross external financing need (in billions of US dollars) $3 /$ In percent of GDP

Key macroeconomic and external assumptions

Real GDP growth (in percent)

Exchange rate appreciation (US dollar value of local currency,

change in percent)

GDP deflator in US dollars (change in percent)

Nominal external interest rate (in percent)

Growth of exports (US dollar terms, in percent)

Growth of imports (US dollar terms, in percent)
I. Baseline Medium-Term Projections

$\begin{array}{rrrrrrrrrrr}64.2 & 64.3 & 59.4 & 46.6 & 41.3 & 40.9 & 34.4 & 30.8 & 26.5 & 22.6 & 19.2 \\ -7.0 & 0.1 & -4.9 & -12.8 & -5.4 & -0.4 & -6.4 & -3.6 & -4.3 & -3.9 & -3.4 \\ -11.4 & 1.4 & -5.7 & -28.8 & -16.0 & -10.2 & -12.8 & -8.2 & -7.9 & -6.0 & -5.8 \\ -11.5 & -2.2 & -3.9 & -20.1 & -15.7 & -10.3 & -10.0 & -7.1 & -6.3 & -4.6 & -3.9 \\ -9.6 & -0.1 & -3.2 & -20.1 & -14.2 & -10.4 & -11.0 & -9.5 & -8.7 & -7.4 & -7.1 \\ 30.9 & 23.0 & 27.4 & 41.7 & 36.6 & 35.0 & 34.1 & 33.0 & 32.1 & 30.9 & 30.2 \\ 21.3 & 22.9 & 24.2 & 21.6 & 22.3 & 24.6 & 23.1 & 23.5 & 23.4 & 23.5 & 23.0 \\ -0.5 & -1.1 & -1.0 & -0.8 & -2.2 & -1.4 & -1.9 & -1.3 & -1.3 & -1.2 & -1.2 \\ 0.5 & 1.1 & 1.0 & 0.8 & 2.2 & 1.4 & 1.9 & 1.3 & 1.3 & 1.2 & 1.2 \\ 0.0 & 0.0 & 0.0 & 0.0 & 0.0 & 0.0 & 0.0 & 0.0 & 0.0 & 0.0 & 0.0 \\ 0.7 & 4.6 & -0.8 & -8.0 & 1.9 & 1.5 & -0.9 & 0.2 & -0.4 & -0.2 & -0.7 \\ 4.4 & 4.1 & 3.9 & 3.2 & 2.8 & 2.2 & 1.9 & 1.7 & 1.5 & 1.3 & 1.1 \\ -0.8 & -3.3 & -2.0 & -1.3 & -1.0 & -1.0 & -1.3 & -1.4 & -1.0 & -0.9 & -0.8 \\ -2.9 & 3.8 & -2.6 & -9.9 & 0.1 & 0.2 & -1.5 & 0.0 & -0.8 & -0.6 & -0.9 \\ 4.4 & -1.3 & 0.8 & 16.1 & 10.6 & 9.8 & 6.4 & 4.6 & 3.6 & 2.1 & 2.4 \\ & & & & & & & & & & \\ 207.7 & 279.9 & 217.1 & 112.0 & 112.8 & 116.8 & 101.0 & 93.5 & 82.7 & 73.1 & 63.7 \\ 4.8 & 5.2 & 3.6 & -6.1 & -3.9 & -1.6 & -2.1 & -0.4 & -0.2 & 0.8 & 0.7 \\ 9.9 & 11.0 & 7.6 & -11.3 & -7.2 & -3.0 & -3.5 & -0.7 & -0.3 & 1.3 & 1.0 \\ & & & & & & & & & & \\ 1.1 & 5.1 & 3.2 & 2.4 & 2.1 & 2.3 & 3.5 & 4.3 & 3.5 & 3.6 & 3.6 \\ -5.1 & -1.8 & -11.7 & -11.7 & -2.5 & -3.1 & 1.0 & -1.9 & -2.0 & -2.3 & -2.3 \\ 1.5 & -6.5 & -2.5 & 10.9 & -1.8 & -2.9 & 4.6 & -1.7 & 0.5 & -0.8 & 0.6 \\ 6.3 & 6.3 & 6.1 & 6.1 & 6.0 & 5.2 & 5.1 & 5.1 & 5.0 & 4.9 & 4.9 \\ -8.5 & -26.9 & 19.9 & 73.0 & -11.3 & -6.3 & 6.9 & -1.1 & 1.4 & -0.3 & 2.7 \\ & 5.5 & 6.2 & 1.6 & 4.4 & 7.8 & 2.8 & 4.1 & 3.9 & 3.8 & 3.3\end{array}$


Table 6 continued. Algeria: External Debt Sustainability Framework, 1997-2007

(In percent of GDP, unless otherwise indicated)

Projections

$2002 \quad 2003 \quad 2004 \quad 2005$

Il. Stress Tests for External Debt Ratio

1. Real GDP growth, nominal interest rate, dollar deflator, non-interest current account, and non-debt inflows are at historical average in 2003-2007

2. Nominal interest rate is at historical average plus two standard deviations in 2003 and 2004

3. Real GDP growth is at historical average minus two standard deviations in 2003 and 2004

4. Change in US dollar GDP deflator is at historical average minus two standard deviations in 2003 and 2004

5. Non-interest current account is at historical average minus two standard deviations in 2003 and 2004

6. Combination of $2-5$ using one standard deviation shocks

7. One time 30 percent nominal depreciation in 2003

$\begin{array}{llllll}40.9 & 41.6 & 39.4 & 36.0 & 30.8 & 25.6 \\ 40.9 & 35.6 & 33.1 & 28.7 & 24.8 & 21.3 \\ 40.9 & 36.9 & 35.8 & 31.4 & 27.5 & 24.0 \\ 40.9 & 44.2 & 48.1 & 43.6 & 39.5 & 35.6 \\ 40.9 & 50.3 & 59.8 & 55.2 & 51.0 & 46.8 \\ 40.9 & 51.9 & 62.3 & 57.6 & 53.4 & 49.1 \\ 40.9 & 37.9 & 34.3 & 30.0 & 26.0 & 22.5\end{array}$

Historical Statisties for Key Variables (past 10 years)

$\begin{array}{ll}\text { Historical } & \text { Standard } \\ \text { Average } & \text { Deviation }\end{array}$

Average

2002-07

Current account defiçit, excluding interest payments

Net non-debt creating capital inflows

Nominal external interest rate (in percent)

Real GDP growth (in percent)

GDP deflator in US dollars (change in percent)

$\begin{array}{rrr}-7.4 & 6.6 & -7.0 \\ 0.6 & 0.7 & 1.4 \\ 6.7 & 0.7 & 5.0 \\ 2.0 & 2.2 & 3.5 \\ -0.2 & 7.8 & 0.1\end{array}$

$1 /$ Derived as $[\mathrm{r}-\mathrm{g}-\mathrm{r}(1+\mathrm{g})+\mathrm{ea}(1+\mathrm{r})] /(1+\mathrm{g}+\mathrm{r}+\mathrm{gr})$ times previous period debt stock, with $\mathrm{r}=$ nominal effective interest rate on external debt; $\mathbf{r}=$ change in domestic GDP deflator in U.S. dollar terms, $\mathrm{g}=$ real GDP growth rate, $\mathrm{e}=$ nominal appreciation (increase in dollar value of domestic currency), and $\mathrm{a}=$ share of domestic currency denominated debt in total external dobt.

2/ The contribution from price and exchange rate changes is defuned as $[-r(1+g)+e a(1+r)] /(1+g+r+g r)$ times previous period debt stock $r$ increases with an apprectating domestic currency ( $\mathrm{e}>0$ ) and rising inflation (based on GDP deflator).

3 / Defined as current account deficit, plus amortization on medium-and long-term debt, plus short-term debt at end of previous period. 


\section{Algeria: Relations WITH THE Fund}

(As of November 30, 2002)

\section{A. Financial Relations}

Membership Status Joined 9/26/63; Article VII

General Resources Account

Quota

Fund holdings of currency

Reserve position in Fund

SDR Department

Net cumulative allocation

Holdings

Outstanding Purchases and Loans

Extended arrangements

Contingency and Compensatory

\section{SDR Million}

$1,254.70$

$2,155.05$

85.08

SDR Million

128.64

2.21

SDR Million

817.81

167.63

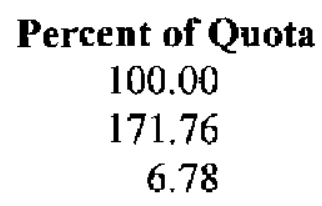

Percent of Allocation

100.00

1.72

\section{Percent of Quota}

65.18

13.36

Financial Arrangements

\begin{tabular}{lcccc} 
Type & $\begin{array}{c}\text { Approval } \\
\text { Date }\end{array}$ & $\begin{array}{c}\text { Expiration } \\
\text { Date }\end{array}$ & $\begin{array}{c}\text { Amount } \\
\text { Approved } \\
\text { (SDR Million) }\end{array}$ & $\begin{array}{c}\text { Amount } \\
\text { Drawn } \\
\text { (SDR Million) }\end{array}$ \\
\hline CCFF & $5 / 07 / 99$ & - & 223.50 & 223.50 \\
EFF & $5 / 22 / 95$ & $5 / 21 / 98$ & $1,169.28$ & $1,169.28$ \\
Stand-by & $5 / 27 / 94$ & $5 / 22 / 95$ & 457.20 & 385.20 \\
Stand-by & $6 / 03 / 91$ & $3 / 31 / 92$ & 300.00 & 225.00
\end{tabular}

Projected Obligations to Fund (SDR million; based on existing use of resources and present holdings of SDRs):

\begin{tabular}{lcrrrrr} 
& Overdue & \multicolumn{5}{c}{ Forthcoming } \\
\cline { 3 - 7 } & & 2002 & 2003 & 2004 & 2005 & \multicolumn{1}{c}{2006} \\
\hline Principal & 0.00 & 7.03 & 306.63 & 250.75 & 181.85 & 133.65 \\
Charges/interest & 0.00 & 0.00 & 25.46 & 17.59 & 11.76 & 7.34 \\
Total & 0.00 & 7.03 & 332.09 & 268.34 & 268.34 & 140.99
\end{tabular}




\section{B. Nonfinamcial Relations}

\section{Exchange Rate Arrangement}

From January 21,1974 to October 1, 1994, the exchange rate of the dinar was determined on the basis of a fixed relationship with a basket of currencies, adjusted from time to time. On October 1, 1994, the Bank of Algeria introduced a managed float for the dinar through daily fixing sessions that include six commercial banks which has been replaced by an interbank foreign exchange market as of January 2, 1996. At the end of November 2002, the average of the buying and selling rates for the U.S. dollar was $\$ 1=$ DA 79.40 . No margin limits are imposed on the buying and selling exchange rates in the interbank foreign exchange market, except for the dollar, where a margin of DA 0.017 has been established between the buying and selling rates of the Bank of Algeria for the dinar against the U.S. dollar.

Algeria maintains an exchange rate system which is free of restrictions on the making of payments and transfers for current international transactions.

\section{Latest Article IV Consultation}

The discussions for the 2001 Article IV consultation and post-program monitoring with Algeria were held in Algiers in May 18-June 3 and July 2-8, 2001. The staff report (EBS/01/130 dated August 3, 2001) was discussed by the Executive Board on August 29, 2001 .

\section{Technical Assistance}

- A MAE technical assistance mission met with representatives of the Bank of Algeria in Geneva from August 15 to 18,1994 to provide advice on the introduction of fixing sessions in the foreign exchange market and transition to an interbank market.

- A staff team from MAE and PDR met with representatives of the Bank of Algeria and commercial banks in Paris from August 21 to 24, 1995 to provide advice on the transformation of existing fixing sessions into an interbank foreign exchange market.

- A FAD technical assistance mission met with the authorities in Rome in September/October 1995 to provide advice on VAT reform.

- A MAE consultant visited Algeria four times in 1998-99 to assess the status of the banking system and provide advice in banking supervision

- MAE consultants visited Algiers in 2000 and 2001 to provide further advice in banking supervision.

- A STA mission visited Algiers in February 2000 and February-March 2001 to provide assistance in the area of monetary statistics.

- A staff team from MED and MAE visited Algiers in April 2000 to advice on banking and monetary issues, and another staff team from MED and FAD visited in May 2000 to help clarify fiscal data issues.

- A FAD mission on tax administration visited Algiers in July 2000. 
- A FAD mission on customs administration visited Algiers in July 2000, and an expert on customs administration visited in March 2001.

- A MAE mission (with MED participation) on review of monetary policy operations visited Algiers in November 2000.

- A FAD mission on budgetary procedures visited Algiers in February 2001.

- Two FAD missions on tariff reform visited Algiers in January and March 2001.

- A FAD mission visited Algiers in December 2001 to advice on the modernization of tax administration.

- A MAE consultant visited Algiers in January, April, July, and October 2002 to assist the Bank of Algeria to develop its banking supervision capability.

- From May 2001 to July 2002, FAD organized periodic visits of a tax administration expert to assist the authorities establish a large taxpayers unit.

- A FAD mission visited Algiers in June-July 2002 to advice on the ongoing process of customs modernization.

- A STA multisector mission visited Algiers during September 4-17, 2002 to assess the system of macroeconomic statistics, including monetary, balance of payments, public finance and national accounts statistics, and price indices.

\section{Resident Representative/Advisor}

None. 


\title{
Algeria: Fthanclal Relations with the World Bank
}

\author{
(As of November 19,2002)
}

The World Bank's portfolio in Algeria has a total of 14 current operations and 58 closed loans, with cumulative net commitments of $\$ 4.6$ billion. Of this total, $\$ 2.8$ billion has been repaid. Net commitments for the 14 current investment operations amount to $\$ 745.9$ million.

In the 1990s, World Bank assistance fluctuated, with strong support in FY 1995 and FY 1996 to the stabilization and adjustment program ( $\$ 759$ million). The security situation, as well as the lack of managerial and technical capacity of some implementing agencies affected project implementation. Following a series of portfolio performance reviews, the government addressed a range of implementation problems with respect to procurement, audit compliance, and disbursement bottlenecks. Efforts to maintain a lean portfolio continue, in full coordination with the authorities. A Country Procurement Assessment Review was undertaken in FY 2002 and is expected to be finalized early 2003. A Country Portfolio Performance Review will be carried out in February 2003.

During the past two years, World Bank relations with Algeria have been revived in a climate of openness and collaboration. The intensification of relations proved effective and an agreement was reached in mid-2001 to prepare a new Country Assistance Strategy (CAS), restart policy dialogue through analytical activities, and establish a field presence in Algiers. The establishment of a liaison office in January 2002 has proved cruciai and successful in improving relations, moving the policy dialogue forward, and improving portfolio implementation.

Lending was renewed in FY 2000 amounting to $\$ 97.5$ million, with three operations covering two strategic fronts: technical assistance for institutional strengthening and reforms, and assistance for emergency situations. Projects approved in FY 2001 and FY 2002, amounting to $\$ 41.7$ million and $\$ 30.7$ million respectively, continued to support the Algerian government in its efforts to implement policy and institutional reforms. They include assistance to:

(a) energy and mining sector ( $\$ 18$ million); (b) budget system modernization ( $\$ 23.7$ million);

(c) transport sector ( $\$ 8.7$ million); (d) financial system infrastructure modernization ( $\$ 16.5$ million) and; (e) mortgage finance ( $\$ 5.5$ million). In FY 2003, the World Bank Executive Board approved an Urban Natural Hazard Vulnerability project ( $\$ 88.5$ million) to respond to the impact of the November 2001 floods.

Key pieces of analytical work were completed, including a social expenditure review, a private sector assessment and a macroeconomic strategy note. A poverty update note and work on a public expenditure review, investment climate, and IT strategy have been initiated. In addition, policy dialogue and advice are being provided to develop sector strategies in rural development and agriculture, housing, water resource management and distribution, transport and environment. A participatory CAS was launched in January 2002 and is being carried out jointly with the government. Core analytical work being carried out will serve as a diagnostic basis for the CAS. 
Algeria: Financial Relations with the World Bank

(As of November 19,2002)

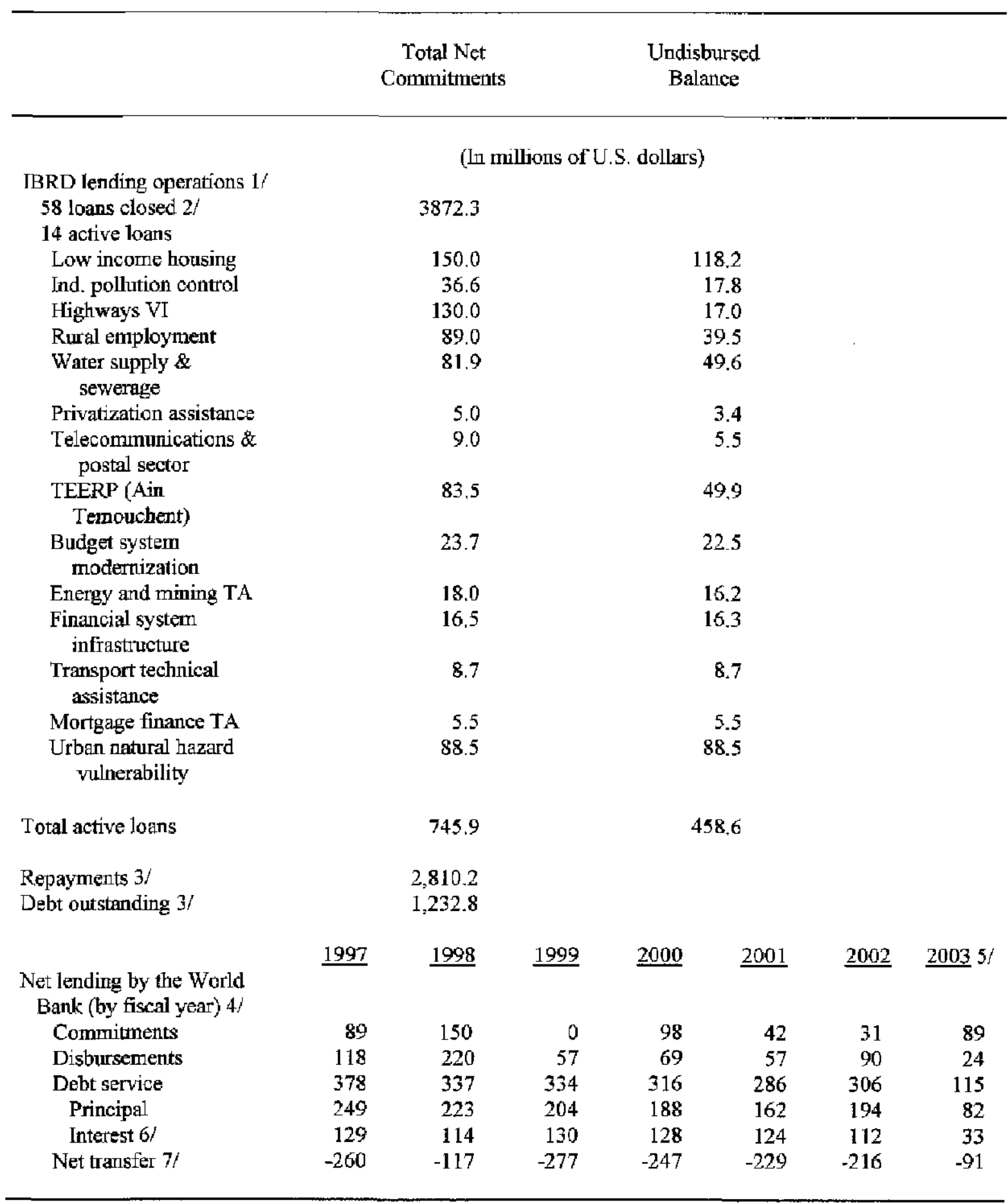

1/ DA has no operations in Algeria.

2/ Less cancellations, includes adjustment lending

3/ As of October 31, 2002. 


\section{Algeria: Statistical Issues}

Following the expiration of the extended arrangement in May 1998, the reporting of statistics to the Fund generally deteriorated, particularly with respect to the quality and timeliness of data forwarded between missions. The lack of financial resources allocated for the compilation of statistics, inter agency coordination, as well as concerns with accuracy and subsequent reluctance to publish provisional data, are partly responsible for this situation. If this trend is not reversed soon and the quality and timeliness of economic data rapidly improved, deterioration may reach a point where it would prevent adequate surveillance.

\section{Real sector}

Real sector data are being reported on an irregular basis with substantial lags to STA. The latest national accounts information in IFS pertains to data reported for 2000. IFS import trade data at current prices are derived from Direction of Trade Statistics. Concerning exports, only volume and price data for petroleum through 1996 have been reported. The September 2002 multisector statistics mission recommended that priority by given to move the compilation of national accounts to 1993 SNA.

\section{Government finance}

Algeria reported government finance statistics (GFS) for the period 1994-2001 for publication in the GFS yearbook. However, the institutional coverage of the data reported is limited to Budgetary Central Government, albeit in a wide sense, including the general budget, the annexed budget, and the special treasury accounts. Clarification has been sought from the authorities regarding the important question of the basis of recording of the latter (net versus gross recording). No sub-annual data are submitted for IFS publication. The September 2002 multisector statistics mission recommended the designation of a coordinator and the assignment of at least one economist for the compilation of GFS. The authorities intend to allocate the duties to the General Director of Accounting. A first task would be the establishment of an automated bridge table between the monthly treasury financial statements (balance générale) and the GFS table (Situation résumée des Opérations du Trésor - SROT) in order to ensure a more timely production of monthly data as well as a more timely report to the Fund of annual and quarterly data on the operations of the treasury. The mission recommended (a) that proceeds of the oil stabilization fund (FRR) be shown as revenue (rather than financing as in the SROT), the compilation of further breakdowns in particular relating to the item "other transfers;" (b) greater detail in data compilation in general and, in particular, to expenditures and other transfers; (c) a more appropriate reporting of debt assumptions over the past decade; and (d) further work on the financing and the reconciliation with monetary statistics. The mission noted that meeting the GDDS and eventually the SDDS standards would require substantial efforts in terms of extension of coverage (consolidating social security and Wilayate operations, and then as a second step other administrative bodies and municipalities). 


\section{Monetary accounts}

Monetary data are broadly adequate for policy formulation and monitoring of economic developments. In particular, coverage has improved, with the consolidation of data from the national savings bank (CNEP). However, reporting of balance sheet data by some commercial banks is very untimely, and most commercial banks do not report complete data that are needed to compile the monetary survey. The September 2002 STA multisector statistics mission recommended expanding further the coverage of the monetary survey to include banking operations of the National Mutual Fund for Agriculture (CNMA) and strictly enforcing the reporting obligations of banks by introducing escalating penalties.

\section{Balance of payments}

The balance of payments compilation system is broadly reliable. However, there is a need to:

(a) improve its coverage by including transactions not covered by the exchange record;

(b) allow reporting to the Fund and publication of quarterly data currently compiled; and

(c) adopt a more rigorous and uniform application of the residency criterion. 


\section{Algeria: Core Statistical Indicators}

(As of November 25, 2002)

\begin{tabular}{|c|c|c|c|c|c|c|c|c|c|c|}
\hline & $\begin{array}{c}\text { Exchange } \\
\text { rate }\end{array}$ & $\begin{array}{c}\text { International } \\
\text { Reserves }\end{array}$ & $\begin{array}{l}\text { Broad } \\
\text { Money }\end{array}$ & $\begin{array}{c}\text { Interest } \\
\text { Rales }\end{array}$ & $\begin{array}{l}\text { Consumer } \\
\text { Price Index }\end{array}$ & $\begin{array}{l}\text { Exports } \\
\text { Imports }\end{array}$ & $\begin{array}{l}\text { Current } \\
\text { Account } \\
\text { Balance }\end{array}$ & $\begin{array}{c}\text { Overall } \\
\text { Government } \\
\text { Balance }\end{array}$ & GDP/GNP & $\begin{array}{l}\text { External } \\
\text { Debt and } \\
\text { Debt } \\
\text { Service }\end{array}$ \\
\hline Date of latest observation & $09 / 30 / 02$ & $11 / 30 / 02$ & $06 / 30 / 02$ & $09 / 30 / 02$ & $09 / 30 / 02$ & $06 / 30 / 02$ & $06 / 30 / 02$ & $06 / 30 / 02$ & $12 / 31 / 01$ & $12 / 31 / 01$ \\
\hline Date received & $10 / 16 / 02$ & $12 / 16 / 02$ & $09 / 15 / 02$ & $10 / 13 / 02$ & $10 / 20 / 02$ & $10 / 16 / 02$ & $10 / 16 / 02$ & $10 / 16 / 02$ & $04 / 07 / 02$ & $04 / 08 / 02$ \\
\hline Frequency of data $1 /$ & M & M & M & $\mathbf{M}$ & $\mathbf{M}$ & $Q$ & $Q$ & $Q$ & A & A \\
\hline $\begin{array}{l}\text { Frequency of } \\
\text { Reporting } 1 /\end{array}$ & $\mathbf{M}$ & M & V & $\mathbf{M}$ & $\mathrm{V}$ & $\mathrm{V}$ & V & V & V & $\mathrm{V}$ \\
\hline Source of data $2 /$ & $A$ & A & A & A & $\mathrm{N}$ & A & A & A & A & A \\
\hline Mode of reporting 3 / & $\mathrm{C}$ & $\mathrm{C}$ & $\mathbf{E}$ & $\mathbf{E}$ & I & $V$ & $\mathrm{~V}$ & V & V & $\mathrm{V}$ \\
\hline Confidentiality 4 ! & $\mathrm{C}$ & C & $\mathrm{C}$ & $\mathrm{C}$ & C & $\mathrm{C}$ & $\mathrm{C}$ & C & $\mathrm{C}$ & C \\
\hline Frequency of publication $1 /$ & M & $M$ & $\mathbf{M}$ & $\mathbf{M}$ & $\mathbf{M}$ & A & A & $Q$ & A & A \\
\hline
\end{tabular}

U/ D-daily; W-Weekly; M-monthly; Q-quarterly, A-annually; V-irregularly in conjunction with stafl visi1s.

2/ A-direct reporting by ceniral bank, ministry of finance, or other official agency; N-official publication or press release; P-commercial publication, C-commercial electronic data provider, E-ELS.

3/ E-electronic data transfer; C-cabie or facsimile; I-Internet website; T-telephone; M-mail; V-staff visits

4/ C-for unfestricted use. 
Algeria: Social Indicators

\begin{tabular}{|c|c|c|c|c|c|}
\hline & 1996 & 1997 & 1998 & 1999 & 2000 \\
\hline \multicolumn{6}{|l|}{ Population } \\
\hline Resident population (in millions) & 28.6 & 29.0 & 29.5 & 30.0 & 30.4 \\
\hline Population aged 0-14 (in millions) & 11.1 & 11.1 & 10.7 & 10.6 & 10.6 \\
\hline Rural population (percent of total) & 42.7 & 41.9 & 41.2 & 40.4 & 39.7 \\
\hline Birth rate (per thousand) & $\ldots$ & 26.5 & $\ldots$ & 25.3 & 24.8 \\
\hline Death rate (per thousand) & 6.0 & 6.1 & $\ldots$ & 5.6 & 5.4 \\
\hline Growth rate (in percent) & 1.8 & 1.7 & 1.6 & 1.5 & 1.5 \\
\hline \multicolumn{6}{|l|}{ Health } \\
\hline Infant Inortality (per thousand) & 37.0 & 35.3 & $\ldots$ & 34.0 & 33.3 \\
\hline Physicians (per thousand people) & $\cdots$ & $\ldots$ & 1.0 & 0.8 & $\cdots$ \\
\hline \multicolumn{6}{|l|}{ Education } \\
\hline Primary School enrollment (percent net) 1 / & 94,1 & $\ldots$ & 108.8 & $\ldots$ & $\ldots$ \\
\hline Secondary School enrollment (percent net) $1 /$ & 56.3 & $\ldots$ & 58.4 & $\ldots$ & $\ldots$ \\
\hline Illiteracy rate $2 /$ & 37.1 & 35.8 & 35.9 & 34.6 & 33.3 \\
\hline \multicolumn{6}{|l|}{ Employment } \\
\hline Labor force (percent of total population) & 31.4 & 32.0 & 32.5 & 33.1 & 33.7 \\
\hline Unemployment (percent of labor force) & $\ldots$ & 28.7 & $\ldots$ & $\ldots$ & $\ldots$ \\
\hline \multicolumn{6}{|l|}{ Income } \\
\hline GDP per capita in U.S. dollars 3/ & $1,641.8$ & $1,649.2$ & $1,604.9$ & $1,589.1$ & $1,753.5$ \\
\hline
\end{tabular}

Source: World Development Indicators (World Bank, 2001)

1/ Percentage of age group over same age group enrolled in education.

$2 /$ In percent of population aged 15 and above.

$3 /$ Converted at the official average exchange rate. 


\section{INTERNATIONAL MONETARY FUND}

Public Information Notice

EXTEPKAA:

MELAIIONS

DPASMISN
Public Information Notice (PIN) No. 03/25

FOR IMMEDIATE RELEASE

March 5, 2003
International Monetary Fund

$70019^{\text {th }}$ Street, NW

Washington, D. C. 20431 USA

\section{IMF Concludes 2002 Article IV Consultation with Algeria}

On February 24, 2003, the Executive Board of the International Monetary Fund (IMF) concluded the Article IV consultation with Algeria. ${ }^{1}$

\section{Background}

After restoring-under particularly difficult circumstances-macroeconomic stability with Fund support, Algeria adopted a conservative macroeconomic policy stance in 1999-2000. This prudent fiscal stance, coupled with high oil revenues, was reflected in a major strengthening of the balance of payments position, an improvement in the external debt indicators, and a marked decline in the inflation rate.

Faced with mounting social cemands-and in the context of large treasury deposits accumulated at the central bank-the government decided to ease fiscal policy starting in 2001 until private activity generates sufficient employment opportunities. It adopted a fiscal stimulus plan covering the $2001-04$ period.

As a result, the overall budget balance weakened in 2001 and the first half of 2002 . This deterioration mainly reflected higher spending and a decline in hydrocarbon revenues due to a reduction in volumes and prices. The overall balance dropped from a surplus of 9.8 percent of GDP in 2000 to a surplus of 3.4 percent of GDP in 2001 and to a small deficit in the first half of 2002.

\footnotetext{
${ }^{1}$ Under Article IV of the IMF's Articles of Agreement, the IMF holds bilateral discussions with members, usually every year. A staff team visits the country, collects economic and financial information, and discusses with officials the country's economic developments and policies. On return to headquarters, the staff prepares a report, which forms the basis for discussion by the Executive Board. At the conclusion of the discussion, the Managing Director, as Chairman of the Board, summarizes the views of Executive Directors, and this summary is transmitted to the country's authorities.
} 
The balance of payments remained in surplus in 2001 and during the first half of 2002, notwithstanding a drop of 4 percent of GDP in the current account in 2001. In the first half of 2002, the current account surplus decreased further as hydrocarbon exports continued to decline and imports increased. The capital account deficit narrowed in 2001 and the first half of 2002, mainly as a result of increased net direct investments - which were boosted in part by the sale of a second cellular telephone license in 2001-higher drawings, and lower amortization. Gross official reserves surged from US\$11.9 billion (12 months of imports) at end-2000 to US\$21.1 bilion at end-June 2002. Following a trend that began in 1996, gross external debt continued to decrease to US $\$ 22.6$ billion at end 2001 (from US $\$ 25.3$ billion at year-end 2000).

Lower hydrocarbon output was partly offset by a better performance in nonhydrocarbon sectors. The overall GDP growth of 2.1 percent was marginally lower than that in 2000 despite a sharp rebound in the nonhydrocarbon sector, which rose to 4.5 percent (from 1.5 percent in 2000). Preliminary data for the first half of 2002 indicate divergent evolutions in different sectors - with a decline in agriculture due to adverse weather conditions and a pickup in construction and service activities due to the government's fiscal stimulus. As a result of the stronger growth of the nonhydrocarbon sector (particularly in agriculture), the unemployment rate decreased from 29.5 percent in 2000 to 27.3 percent in 2001. Average inflation, as measured by the consumer price index (CPI), increased from 0.3 percent in 2000 to 4.2 percent in 2001 due in part to a wage increase granted at the beginning of 2001 and to higher food prices. In the first eleven months of 2002 , the CPI fell by 2.2 percent relative to December 2001 mainly due to a drop in food prices.

Regarding structural reforms, some progress has been achieved in two areas: economic liberalization and privatization/public sector restructuring. Regarding the first, a comprehensive tariff reform was implemented. Algeria signed an Association Agreement with the European Union in April 2002 and negotiations toward accession to the World Trade Organization (WTO) are ongoing. In addition, the parliament approved a law liberalizing the electricity and gas sectors, and an ordinance reforming the tax code was issued. On privatization, two major transactions were completed in mid-2001: (a) the assets of the public sector steel-making complex, SIDER, were transferred to a majority foreign-owned company; and (b) a new cellular telephome license was sold to a private investor. In addition, the institutional framework for the management of public sector enterprises was revised with a view to providing the government with more flexibility.

\section{Executive Board Assessment}

Executive Directors commended the authorities for preserving the macroeconomic stability achieved in recent years, and for making progress in a number of structural reform areas, in particular in trade liberalization. Aided by higher cil prices, these policies have contributed to a marked strengthening of the balance of payments, an increase in official reserves, and a sharp decline in inflation.

Directors agreed that its favorable macroeconomic position provides Algeria with a timely opportunity to address its main challenges of raising economic growth, reducing unemployment, and improving living standards on a sustained basis. Building on the progress 
made to date, this will require a redoubling of structural reform efforts, along with the continued pursuit of sound macroeconomic policies.

Directors noted that the authorities' Economic Recovery Plan (ERP) entails a substantial fisca| stimulus. They recognized that this fiscal expansion will not endanger the external and treasury positions as long as oil prices remain high, and that an increase in human capital and infrastructure investments is made possible by Algeria's prudent policy record. At the same time, however, Directors stressed that fiscal stimulus will boost growth only temporarily, and cannot substitute for the more fundamental reforms that are needed to achieve a lasting improvement in growth and employment creation. They also cautioned that an expansionary fiscal policy could ratchet up expenditures that might be difficult to reverse and thus increase the budget's vulnerability to adverse developments in the oil markets, and that it could lead to excess demand and price pressures. In addition, this policy could weaken the purpose of the oil stabilization fund. Directors were encouraged that the authorities were mindful of these risks, and that they consider the ERP as a supplement, not a substitute, to structural reforms. They urged them to adhere to sufficiently cautious fiscal policies, in particular, by scaling down expenditures over time, priaritizing them according to their role in supporting structural reforms and generally enhancing the efficiency of public spending. Directors also highlighted the importance of continued efforts to enhance and widen the fiscal revenue base. The forthcoming fiscal Report on Standards and Codes will help identify measures to strengthen the budget process.

Directors welcomed the authorities' resolve to devote monetary policy to preserving price stability. This will require continued vigilance in the period ahead, given the fiscal easing and the inflationary pressures that could be generated by a further rapid increase in money growth. Directors commended the authorities for the introduction of a new instrument to absorb excess liquidity, and encouraged them to take further steps to deepen the financial markets by offering a broader spectrum of savings instruments.

Directors welcomed the authorities' commitment to manage the exchange rate float in a flexible way to dampen external shocks. They encouraged the authorities to take advantage of the strong international reserve position to liberalize further the exchange system and strengthen the role of market forces in exchange rate determination. Directors commended the authorities for continuously reducing the level of external debt over the years. They encouraged them to engage in a more active debt management aimed at reducing the cost and lengthening the maturity of external liabilities, and to continue to work towards the resolution of bilateral debt issues.

Directors viewed the increased private activity and the rise in foreign direct investment as welcome signs that past reforms are bearing fruits. They agreed that the sustained implementation of a comprehensive structural and institutional reform agenda, with particular focus on promoting private sector activity in the non-hydrocarbon sectors, will be key to achieving sustained growth and job creation over the medium term. Directors therefore urged the authorities to redouble their reform efforts, with a special emphasis on privatization and public sector restructuring, and steps to further open up the economy and improve the business environment. 
Directors welcomed the completion of two sizable privatization transactions in 2001 and the approval of a list of 40 public enterprises to be privatized, and urged the authorities to move ahead with the remaining privatization agenda in a timely and measured fashion. They stressed the need for transparent and efficient procedures, and an extended social safety net to mitigate the negative impact of public sector restructuring on labor. Directors also locked forward to continued efforts to improve governance, strengthen institutions-including the judiciary-and clarify the property rights on agricultural land.

Directors encouraged further steps toward establishing a sound banking system operating on a more commercial footing, including through privatization. In the period ahead, credits to lossmaking public enterprises should be replaced with direct and temporary budget subsidies, and efforts should be made to improve banks' efficiency and management capacity, especially in the area of risk assessment. Directors welcomed Algeria's participation in the Financial Sector Assessment Program, which will lay the basis for future steps to strengthen the financial sector. They also welcomed the authorities' commitment to combating money laundering and the financing of terrorism, and looked forward to the enactment of comprehensive legislation in this area.

Directors commended the authorities for achieving major progress in trade liberalization and their commitment to open up further in the period ahead. Recent steps include the implementation of a comprehensive tariff reform, the signing of an Association Agreement with the European Union, and the resumption of negotiations towards WTO accession. Going forward, Directors encouraged the authorities to further reduce the multilateral tariff rates to avoid risks of trade diversion and facilitate customs administration, and supported efforts towards regional economic integration. The authorities were also encouraged to continue to work towards full participation in the HIPC Initiative.

Directors highlighted the importance of continued strong efforts to address statistical deficiencies that hamper economic assessment and the formulation of economic policies. They welcomed the authorities' interest in the Fund's Special Data Dissemination Standard as a framework for statistics development.

Publlc Information Notices (PINS) are issued, (i) at the request of a member country, following the conclusion of the Article IV consultation for countries seeking to make known the views of the IMF to the public. This action is intended to strengthen IMF surveillance over the economic policies of member countries by increasing the transparency of the IMF's assessment of these policies; and (ii) following policy discussions in the Executive Board at the decision of the Board. 


\section{Algeria: Selected Economic Indicators}

\begin{tabular}{|c|c|c|c|c|c|}
\hline & 1997 & 1908 & 1099 & 2000 & 2001 \\
\hline Domestic өconomy & \multicolumn{5}{|c|}{ (In percent) } \\
\hline Real GDP & 1.1 & 5.1 & 3.2 & 2.4 & 2.1 \\
\hline GDP deflator & 6.5 & $-3,8$ & 10.9 & 23.9 & 1.4 \\
\hline Consumer price index $(\mathrm{CP})$, periad average & 5.7 & 5.0 & 2.6 & 0.3 & 4.2 \\
\hline External sector & \multicolumn{5}{|c|}{ (In billions of U.S. dollars) $\mathrm{N}$} \\
\hline Exports of goods, f.o.b. & 13.8 & 10.1 & 12.3 & 21.7 & 19.1 \\
\hline Imports of goods, f.o.b. & -8.1 & -8.6 & -9.0 & -9.3 & -8.5 \\
\hline $\begin{array}{l}\text { Current account, excluding capital grants (in percent of } \\
\text { GDP) }\end{array}$ & 7.2 & -1.9 & 0.0 & 16.9 & 12.9 \\
\hline Capital account balance & -2.3 & -0.8 & -2.4 & -1.6 & -0.9 \\
\hline Gross official reservę & 8 & 6.8 & 4.4 & 11.9 & 18 \\
\hline External debt (in percent of GDP) & 65.2 & 64.3 & 58.6 & 46.6 & 41.3 \\
\hline Debt service ratio (in percent of exports) & 29.8 & 46.3 & 40.3 & 20.3 & 22.8 \\
\hline Real effective exchange rate (percentage change) $2 /$ & 9.9 & 4.8 & -7.9 & -2.5 & 2.8 \\
\hline Financial variables & \multicolumn{5}{|c|}{ (In percent of GDP) 1 ) } \\
\hline Overall budget balance & 2.4 & -3.8 & -0.5 & 9.8 & 3.4 \\
\hline Change in broad money (M2) (in percent) & 18.2 & 47.2 & 12.4 & 13.0 & 22.3 \\
\hline Interest rate (central bank rediscount rate, in percent) & 11.0 & 9.5 & 8.5 & 6.0 & 6.0 \\
\hline
\end{tabular}

Sources: Data provided by the Algerian authorities; and IMF staff estimates.

1/ Unless otherwise noted.

2/ A decrease in the index implies a depreciation. 


\section{Statement by the IMF Staff Representative on Algeria February 24, 2003}

Since the staff report was issued, the staff received the following information which does not change the thrust of the staff appraisal:

- Reflecting stronger-than-expected hydrocarbon export volumes in the latter part of the year, hydrocarbon export proceeds reached $\$ 18.0$ billion in 2002 (from a projected amount of $\$ 17.5$ billion).

- Gross foreign exchange reserves increased to $\$ 23.1$ billion at end-December 2002 (20.5 months of goods and services) and to $\$ 24.3$ billion at end-January 2003 from a projected amount of $\$ 22.5$ billion in the staff report for December 2002.

- The outstanding stock of medium- and long-term external debt reached $\$ 22.7$ billion at end-2002 (against a projected stock of $\$ 21.6$ billion for 2002). The increase appears to be due to somewhat higher drawings ( $\$ 1.4$ billion against a projected amount of $\$ 1.1$ billion) and to valuation effects (rise in the euro exchange rate vis-à-vis the U.S. dollar).

- Treasury deposits at the Bank of Algeria rose to DA 430.6 billion at endDecember 2002 (i.e., 10.1 percent of the projected 2002 GDP) from DA 414.1 billion at end-December 2001 (9.8 percent of the 2001 GDP).

- Monetary data at end-September 2002 (latest figures available for the banking system) show a growth of money and quasi money of 22.4 percent over September 2001.

- The 12-month average inflation rate (as measured by the consumer price index, CPI) was 1.4 percent, as projected in the staff report. Owing in part to a further rise in food prices, the monthly inflation rate edged up by 0.7 percent in December 2002 (and 2.4 percent in November 2002),

- $\quad$ The 12-month moving average real effective exchange rate to November 2002 showed a depreciation of the dinar by 6.1 percent.

- The Algerian press recently reported that the trade union Union Générale des Travailleurs Algériens (UGTA) called for a general strike on February 25 and 26,2003 in support of demands for increased transparency in the government's privatization policies and a wage increase. 